Supplementary Information for:

\title{
Live cell discovery of microbial vitamin transport and enzyme-cofactor interactions
}

Lindsey N. Anderson, ${ }^{\dagger}$ Phillip K. Koech ${ }^{\dagger}$ Andrew E. Plymale, ${ }^{\dagger}$ Elizabeth V. Landorf,,${ }^{\dagger}$ Allan Konopka, ${ }^{\dagger}$ Frank R. Collart, ${ }^{\dagger}$ Mary S. Lipton, ${ }^{\dagger}$ Margaret F. Romine, ${ }^{\dagger}$ Aaron T. Wright ${ }^{\dagger *}$

${ }^{\dagger}$ Biological Sciences Division, Pacific Northwest National Laboratory, Richland, WA, 99352 USA

Biosciences Division, Argonne National Laboratory, Argonne, IL, 60439 USA

*Corresponding Author:

Aaron T Wright

Aaron.Wright@pnnl.gov

902 Battelle Blvd, MSIN J4-02

Richland, WA 99352

(509) 372-5920 (office) 


\section{Supplementary Figures}

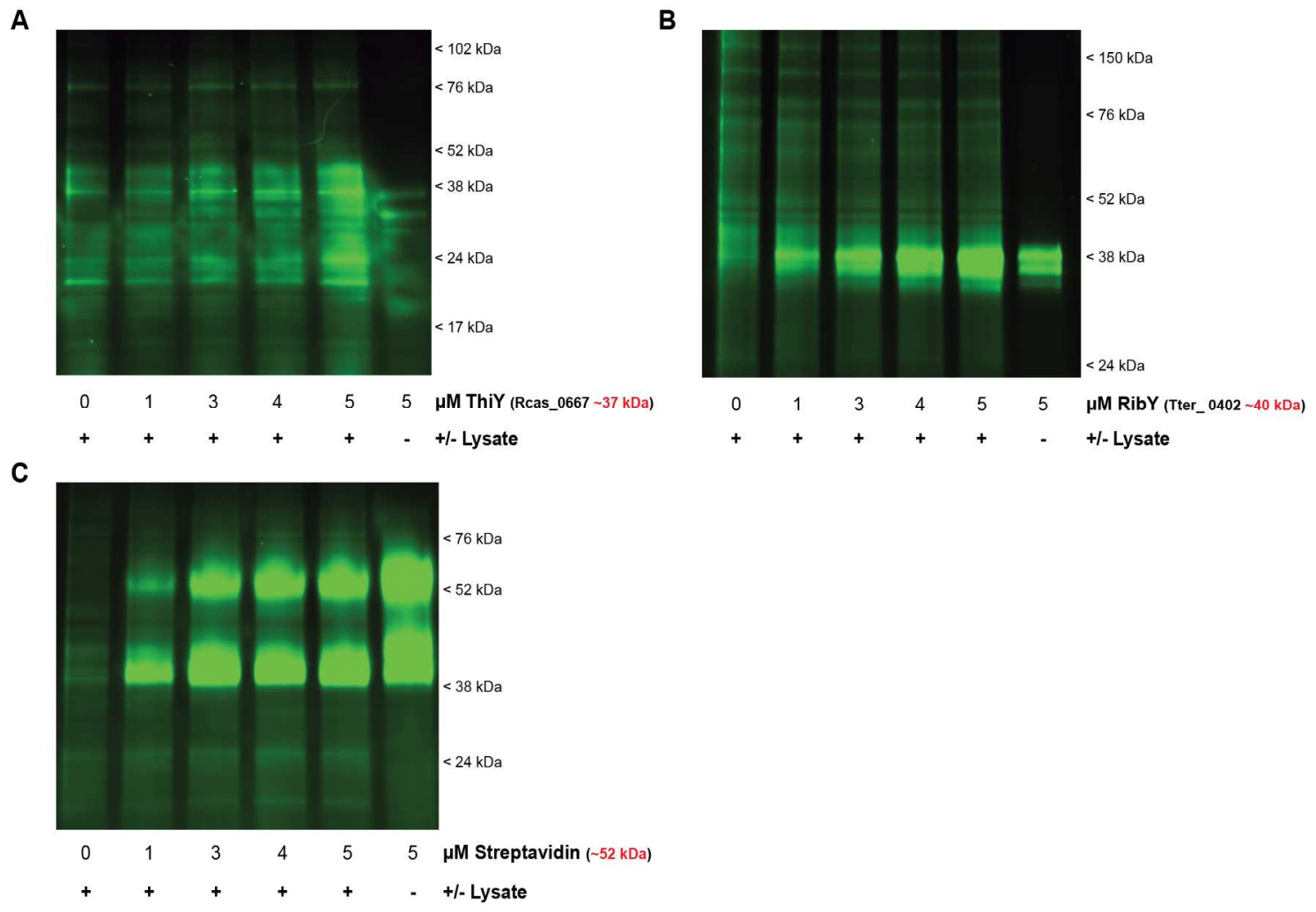

Supplementary Figure S1. Chloroflexus aurantiacus was cultured in three separate cultures, with $\mathrm{B}_{1}$ (Thiamine), $\mathrm{B}_{2}$ (Riboflavin), or $\mathrm{B}_{7}$ (Biotin) being limited, respectively. Cell lysates were labeled with corresponding probes $\mathbf{B}_{1^{-}}$, $\mathbf{B}_{2^{-}}$, or $\mathbf{B}_{7}-\mathbf{A B P}(20 \mu \mathrm{M})$ and doped with pure proteins $(0-5 \mu \mathrm{M})$ known to be labeled by each respective probe (see manuscript Figure 3). (A) $\mathbf{B}_{\mathbf{1}}$-ABP labeling of thiamine limited cell lysate doped with ThiY (Rcas_0667, bands at $\sim 37 \mathrm{kDa}$ ). Interestingly, the pure ThiY seems to overlap with the C. aurantiacus ThiY, which has an almost identical molecular weight. (B) $\mathbf{B}_{2}$-ABP labeling of riboflavin limited cell lysate doped with RibY (Tter_0402, 40 $\mathrm{kDa})$. (C) $\mathbf{B}_{7}$-ABP labeling of biotin limited cell lysate doped with streptavidin ( $\left.\sim 52 \mathrm{kDa}\right)$. 


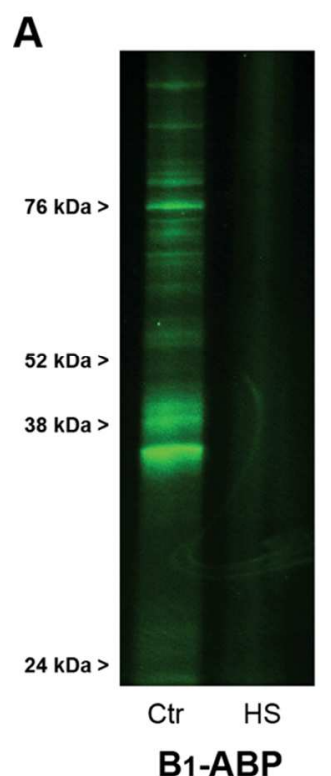

- B1

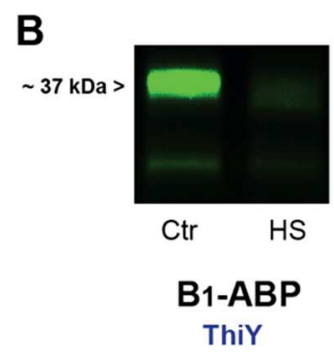

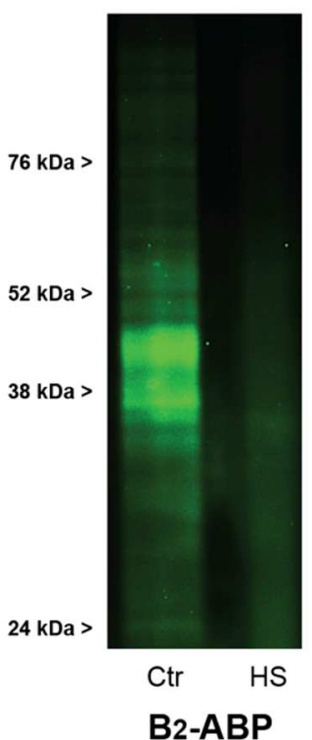

- B2

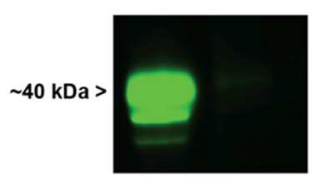

Ctr HS

B2-ABP

RibY

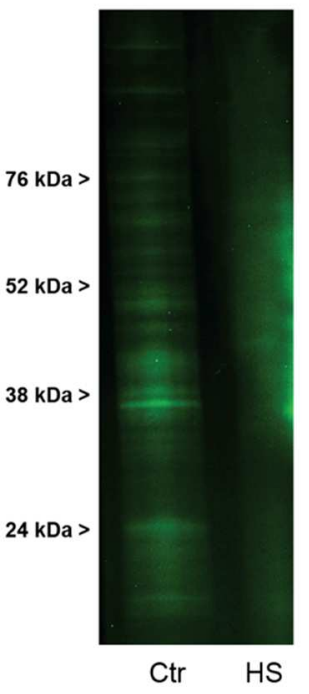

B7-ABP

- B7

Supplementary Figure S2. Chloroflexus aurantiacus was cultured in three separate cultures, with $\mathrm{B}_{1}$ (Thiamine), $\mathrm{B}_{2}$ (Riboflavin), or $\mathrm{B}_{7}$ (Biotin) being limited, respectively. The lysates (panel A) and pure proteins (panel B) were labeled with appropriate probes $\mathbf{B}_{\mathbf{1}^{-}}, \mathbf{B}_{\mathbf{2}^{-}}$, and $\mathbf{B}_{7^{-}} \mathbf{A B P}(20 \mu \mathrm{M})$, either under optimal labeling conditions $\left(37^{\circ} \mathrm{C}\right.$ for pure proteins, $52{ }^{\circ} \mathrm{C}$ for lysate), or following heatshock (HS; $95{ }^{\circ} \mathrm{C}$ for $10 \mathrm{~min}$ ) treatment. (A) C. aurantiacus cell lysates were labeled with corresponding probe and compared against the heatshock control. (B) B vitamin pure proteins were labeled with corresponding probe and compared against the heatshock control. 


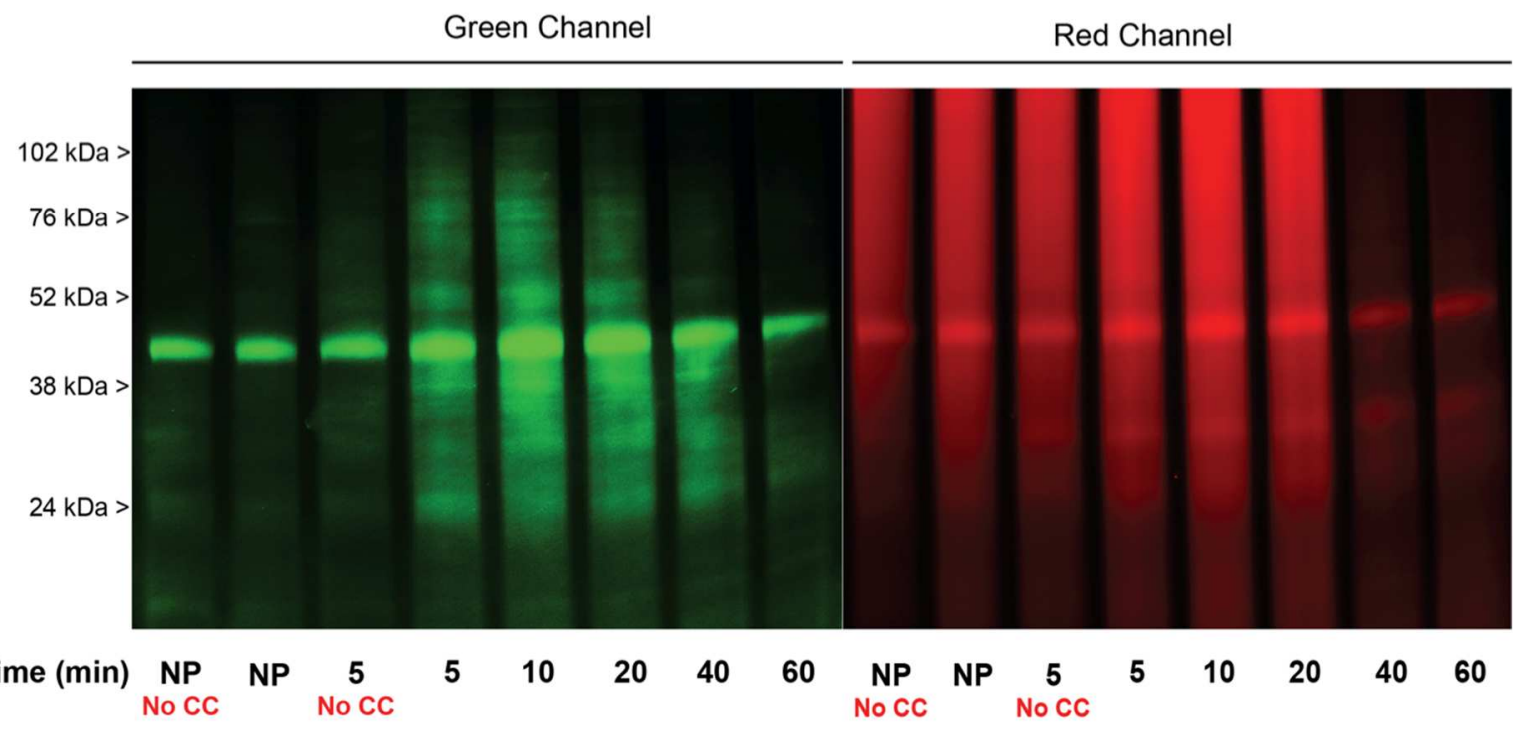

Supplementary Figure S3. B $_{2}$-limited C. aurantiacus cell lysates were used to establish a time-dependent labeling gradient using corresponding $\mathbf{B}_{\mathbf{2}}-\mathbf{A B P}(20 \mu \mathrm{M})$ with the following labeling controls: NP with no click chemistry (No CC), NP with click chemistry to a fluorophore, and $\mathbf{B}_{2}-\mathbf{A B P}$ with no CC. Time labeling controls were incubated at $52{ }^{\circ} \mathrm{C}$ at various time points up to an hour to establish an optimized time of labeling. The red channel shows a strong autofluorescent protein band at $\sim 42 \mathrm{kDa}$; probe labeling begins at $5 \mathrm{~min}$ as demonstrated in the green channel image.

Live Cell Labeling of B Vitamin Limited $C$. aurantiacus

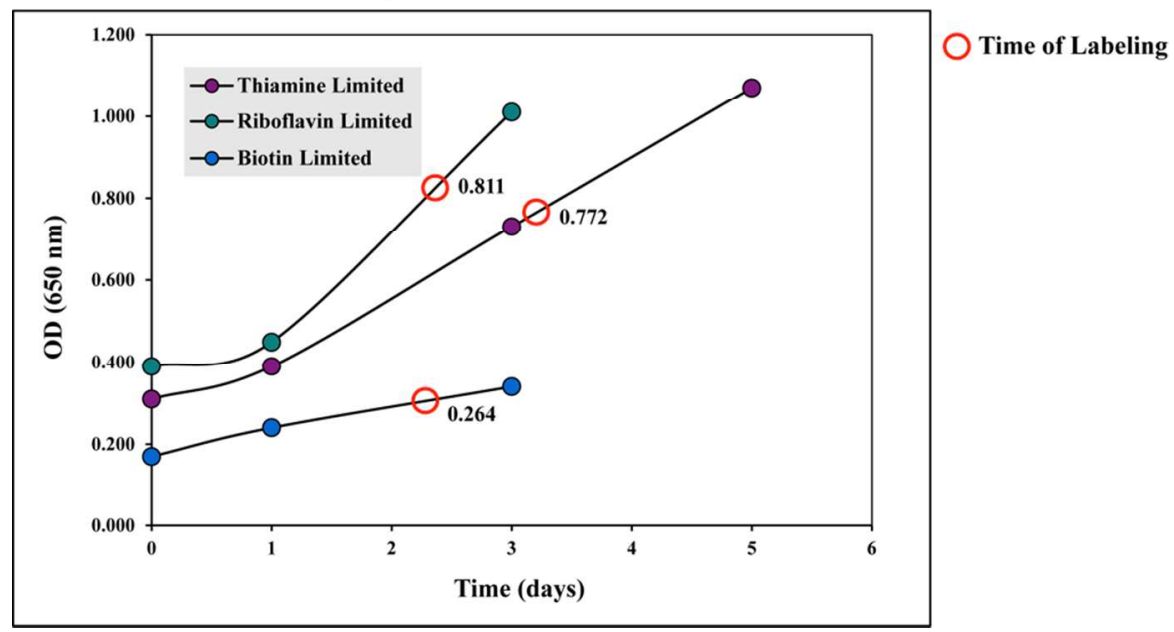

Supplementary Figure S4. C. aurantiacus cultures grown with limited B vitamins were collected, and optical density (OD) values were measured to confirm early to mid-log phase growth that was used to probe labeling (indicated by red circle). 


\section{Supplementary Datasets}

Dataset Key. Full description of all terms and column headings used throughout Supplementary Datasets S1-S6.

Dataset S1. Proteomic analysis of in vivo $\mathrm{B}_{1}$-ABP labeled vitamin $\mathrm{B}_{1}$ limited (L) cultures of $C$. aurantiacus. Protein abundances shown were determined by the accurate mass and time (AMT) tag method and are given as $\log _{2}$ values; spectral counts (SC) are also provided. Fold change (FC) differences in abundances measured by the AMT tag approach were calculated between the probe and (1) no probe with click chemistry (NP) controls, and (2) no probe without click chemistry (NPnoCC) controls.

Dataset S2. Shared proteins identified by global proteomic analysis of Chloroflexus aurantiacus by tagfree quantitative accurate mass and time (AMT) and spectral count (SC) analyses. The bacterium was grown in $\mathrm{B}_{1^{-}}, \mathrm{B}_{2^{-}}$, and $\mathrm{B}_{7^{-}}$limited (L) conditions.

Dataset S3. Proteomic analysis of in vivo $\mathrm{B}_{2}$-ABP labeled vitamin $\mathrm{B}_{2}$ limited (L) cultures of $C$. aurantiacus. Protein abundances shown were determined by the AMT tag method and are given as $\log _{2}$ values; spectral counts are also provided. Fold change differences in abundances measured by the AMT tag approach were calculated between the probe and (1) no probe with click chemistry (NP) controls, and (2) no probe without click chemistry (NPnoCC) controls.

Dataset S4. Proteomic analysis of in vivo $\mathrm{B}_{7}-\mathrm{ABP}$ labeled vitamin $\mathrm{B}_{7}$ limited (L) cultures of $C$. aurantiacus. Protein abundances shown were determined by the AMT tag method and are given as $\log _{2}$ values; spectral counts are also provided. Fold change differences in abundances measured by the AMT tag approach were calculated between the probe and (1) no probe with click chemistry (NP) controls, and (2) no probe without click chemistry (NPnoCC) controls.

Dataset S5. Proteomic analysis of in vitro $B_{7}-A B P$ labeled vitamin $B_{7}$ limited (L) cultures of $C$. aurantiacus. Protein abundances shown were determined by the AMT tag method and are given as $\log _{2}$ values; spectral counts are also provided. Fold change differences in abundances measured by the AMT tag approach were calculated between the probe and (1) no probe with click chemistry (NP) controls, and (2) no probe without click chemistry (NPnoCC) controls. 
Dataset S6. Unique proteins identified in the individual $\mathrm{B}_{1^{-}}, \mathrm{B}_{2^{-}}$, and $\mathrm{B}_{7^{-}}$-limited (L) conditions by global proteomic analysis of Chloroflexus aurantiacus.

\section{Supplementary Methods}

General Procedures and Materials. All reactions were run under an atmosphere of nitrogen, unless otherwise indicated. Solvents were transferred via plastic syringe or a dropping funnel. Flasks were oven-dried and cooled under vacuum. 4-methyl-5-thiazoleacetic acid 1, N-(3-dimethylaminopropyl)-Nethylcarbodiimide hydrochloride (EDCI), 1-hydroxybenzotriazole hydrate (HOBt), 4-methylmorpholine (NMM), tert-butyldiphenylchlorosilane, imidazole, riboflavin (vitamin $\mathrm{B}_{2}$ ), potassium carbonate, 4(dimethylamino)pyridine (DMAP), tert-butyl bromoacetate, acetic anhydride, $p$-toluenesulfonic acid (PTSA), biotin (vitamin $\mathrm{B}_{7}$ ), N,N-Dimethylformamide (DMF), ethyl acetate (EtOAc), methanol (MeOH), dichloromethane (DCM) were purchased from commercially sources and used without purification. Compound 2 (common "linker") was synthesized according to literature procedures. ${ }^{1}$ High-resolution mass spectra (HRMS) and low-resolution mass spectra (MS) ESI accurate masses are reported for the molecular ion $(\mathrm{M}+1)$ or a suitable fragment ion. Proton nuclear magnetic resonance $\left({ }^{1} \mathrm{H} N M R\right)$ spectra were recorded with a $500 \mathrm{MHz}$ spectrometer. Chemical Shifts are reported in delta $(\delta)$ units, parts per million (ppm) downfield from tetramethylsilane. Coupling constants are reported in Hertz (Hz). Carbon13 nuclear magnetic resonance $\left({ }^{13} \mathrm{C}\right.$ NMR) spectra were recorded with a $500(125.7 \mathrm{MHz})$ spectrometer. Chemical shifts are reported in delta $(\delta)$ units, parts per million $(\mathrm{ppm})$ relative to the center of the triplet at $77.00 \mathrm{ppm}$ for deuterochloroform $\left(\mathrm{CDCl}_{3}\right), 39.5 \mathrm{ppm}$ for $\mathrm{DMSO}_{6}, 206.3 \mathrm{ppm}$ for acetone- $\mathrm{D}_{6}$ $\left(\left(\mathrm{CD}_{3}\right)_{2} \mathrm{CO} .{ }^{13} \mathrm{C}\right.$ NMR spectra were routinely run with broadband. 


\section{Probe Synthesis (Scheme 1).}

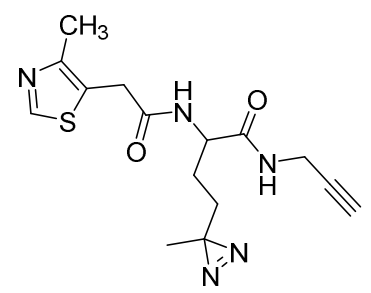

Synthesis of $\mathbf{B}_{1}$-ABP. A solution of 4-methyl-5-thiazoleacetic acid 1 (10.2 mg, 67 $\left.\mu \mathrm{mol}\right)$, EDCI (14.8 mg, $78 \mu \mathrm{mol}), \mathrm{HOBt}(10.5 \mathrm{mg}, 78 \mu \mathrm{mol}), \mathrm{NMM}(43 \mu \mathrm{L}, 0.39 \mathrm{mmol})$ in DMF $(0.5 \mathrm{~mL})$ was stirred at $25^{\circ} \mathrm{C}$ for $15 \mathrm{~min}$. Compound 3 in $\operatorname{DMF}(0.5 \mathrm{~mL})$ was added to the resulting yellow solution and then the reaction mixture was allowed to stir at $25{ }^{\circ} \mathrm{C}$ overnight. The reaction mixture was diluted with water (10 $\mathrm{mL})$ and then extracted with EtOAc $(3 \times 5 \mathrm{~mL})$, the combined organics was washed with water $(3 \times 5$ $\mathrm{mL}), 10 \%$ citric acid $(1 \times 5 \mathrm{~mL})$, brine $(2 \times 5 \mathrm{~mL})$ and dried over $\mathrm{Ca}_{2} \mathrm{SO}_{4}$. Evaporation of the solvents, followed by flash column chromatography $\left(\mathrm{SiO}_{2}, 5 \% \mathrm{MeOH}\right.$ in $\mathrm{DCM}$ to $100 \% \mathrm{MeOH}$ gradient) gave compound $\mathbf{B}_{1}$-ABP $(11.5 \mathrm{mg}, 69 \%) .{ }^{1} \mathrm{H}$ NMR $\left(\left(\mathrm{CD}_{3}\right)_{2} \mathrm{CO}\right) \delta 9.21(\mathrm{~s}, 1 \mathrm{H}), 7.78(\mathrm{~s}, 1 \mathrm{H}), 7.72-70(\mathrm{~d}, J=$ $10 \mathrm{~Hz}, 1 \mathrm{H}), 4.43-4.39$ (q, $J=5 \mathrm{~Hz}, 1 \mathrm{H}), 3.99-3.97(\mathrm{dd}, J=10,5 \mathrm{~Hz}, 2 \mathrm{H}), 3.88(\mathrm{~s}, 2 \mathrm{H}), 2.68-2.67(\mathrm{t}, J=$ 5Hz, 1H), $2.44(\mathrm{~s}, 3 \mathrm{H}), 1.75-1.68(\mathrm{~m}, 2 \mathrm{H}), 1.44-1.39(\mathrm{~m}, 2 \mathrm{H}), 0.98(\mathrm{~s}, 3 \mathrm{H}) .{ }^{13} \mathrm{C}$ NMR (DMSO-d6) $\delta$ $171.1,169.2,151.7,149.6,125.1,81.4,73.5,59.0,49.4,34.8,32.8,30.6,26.1,19.7,15.3$ ESI MS calculated $[\mathrm{M}+\mathrm{H}+]$ for $\mathrm{C}_{15} \mathrm{H}_{19} \mathrm{~N}_{5} \mathrm{O}_{2} \mathrm{~S} 334.1$; found 334.0, HRMS [M+Na] 356.114. 
${ }^{1} \mathrm{H} \mathrm{NMR}\left(\mathrm{CD}_{3}\right)_{2} \mathrm{O}$

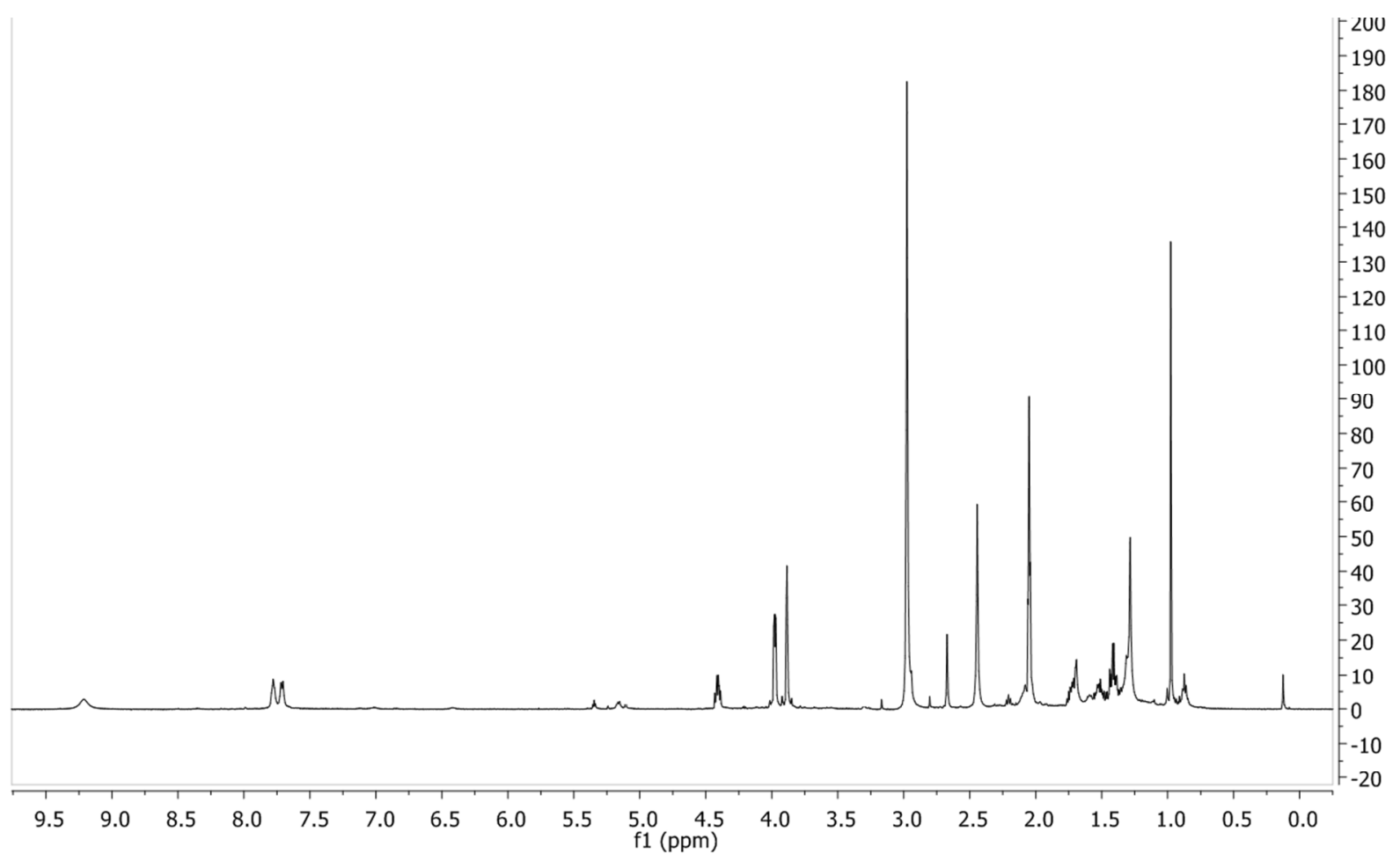

${ }^{13}$ C NMR (DMSO-d6)

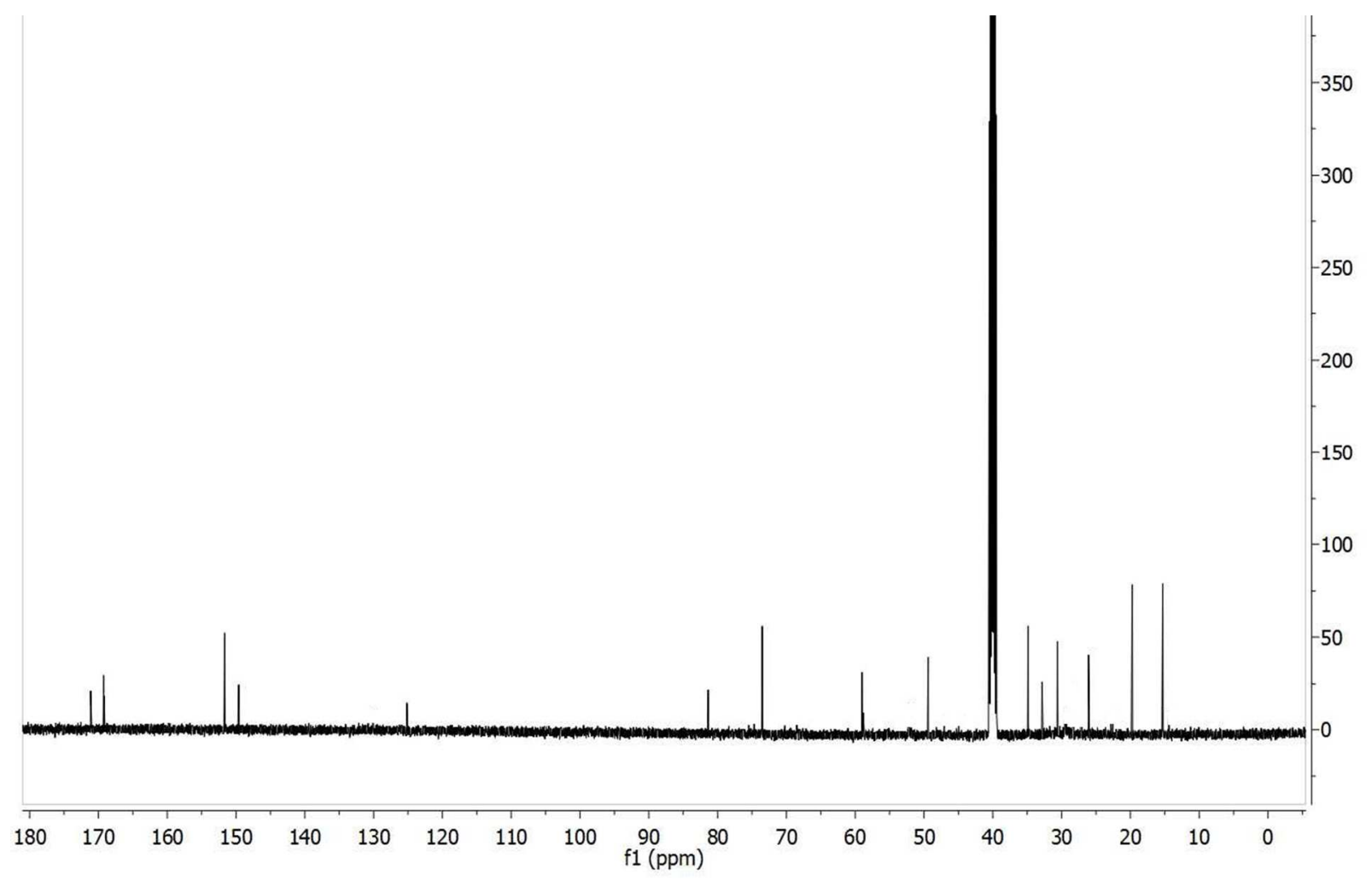




\section{Synthesis of $\mathbf{B}_{2}$-ABP.}

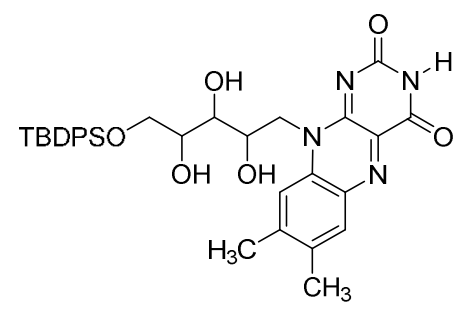

Compound 3. To a solution of vitamin $\mathrm{B}_{2}(0.20 \mathrm{~g}, 0.53 \mathrm{mmol})$, tert-butyldiphenylchlorosilane $(0.17 \mathrm{~g}$, $0.64 \mathrm{mmol})$ in DMSO $(5 \mathrm{~mL})$, was added imidazole $(25.3 \mathrm{mg}, 0.372 \mathrm{mmol})$ in one portion. The resulting mixture was allowed to stir at room temperature for $24 \mathrm{~h}$. After which the reaction mixture was diluted with water to precipitate out a yellow solid. This solid was filtered and washed with water $(3 \times 10 \mathrm{~mL})$, dried and purified by flash chromatography $\left(\mathrm{SiO}_{2}, 5 \% \mathrm{MeOH}\right.$ in DCM to $100 \% \mathrm{MeOH}$ gradient) to afford compound 3 (70 mg, 21\%). ${ }^{1} \mathrm{H}$ NMR $\left(\right.$ DMSO-d $\left._{6}\right) \delta 11.32(\mathrm{~s}, 1 \mathrm{H}), 7.84(\mathrm{~s}, 1 \mathrm{H}), 7.64(\mathrm{t}, J=5 \mathrm{~Hz}, 4 \mathrm{H})$, 7.37 (quin, $J=5 \mathrm{~Hz}, 6 \mathrm{H}), 5.15(\mathrm{~d}, J=5 \mathrm{~Hz}, 1 \mathrm{H}), 5.01(\mathrm{~d}, J=5 \mathrm{~Hz}, 1 \mathrm{H}), 4.85(\mathrm{~m}, 1 \mathrm{H}), 4.82(\mathrm{~d}, J=5 \mathrm{~Hz}$, 1H), $4.60(\mathrm{~d}, J=5 \mathrm{~Hz}, 1 \mathrm{H}), 4.24(\mathrm{~s}, 1 \mathrm{H}), 3.84(\mathrm{~s}, 2 \mathrm{H}), 3.68(\mathrm{t}, J=5 \mathrm{~Hz}, 2 \mathrm{H}) 2.45(\mathrm{~s}, 3 \mathrm{H}), 2.40(\mathrm{~s}, 2 \mathrm{H}), 2.34$ $(\mathrm{s}, 3 \mathrm{H}) 0.94(\mathrm{~s}, 9 \mathrm{H}) .{ }^{13} \mathrm{C}$ NMR $\left(\mathrm{DMSO}_{-} \mathrm{d}_{6}\right) \delta 160.0,155.5,150.9,146.0,136.8,135.7,135.2,134.0$, 133.3, 132.1, 130.7, 129.7, 127.8, 117.4, 73.2, 72.6, 68.7, 66.1, 47.4, 26.7, 20.8, 18.9. ESI MS calculated $\left[\mathrm{M}+\mathrm{H}^{+}\right]$for $\mathrm{C}_{33} \mathrm{H}_{38} \mathrm{~N}_{4} \mathrm{O}_{6} \mathrm{Si}$ 615.2; found 615.3. 


\section{${ }^{1}$ H NMR (DMSO-d6)}

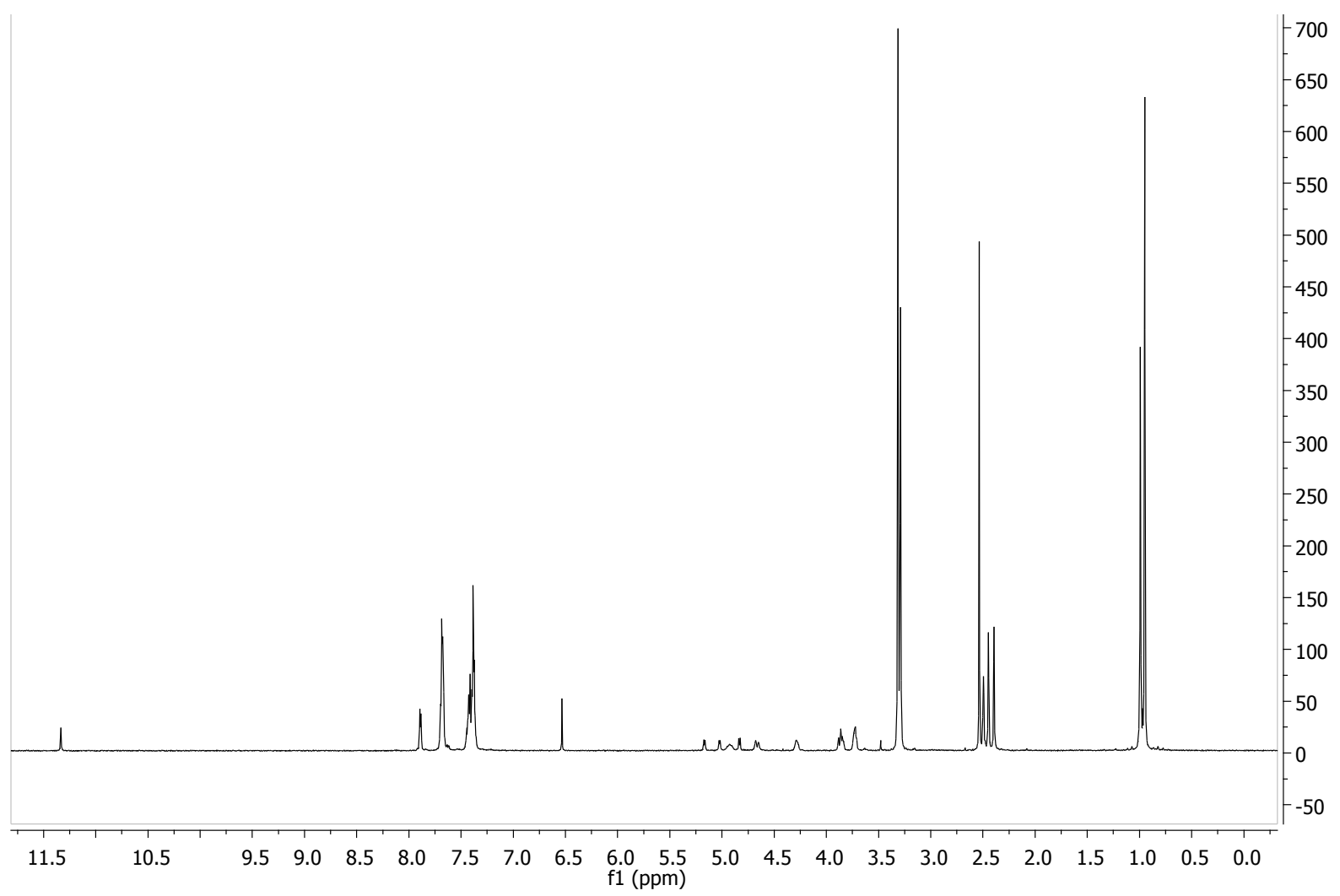

${ }^{13} \mathrm{C}$ NMR (DMSO-d6)

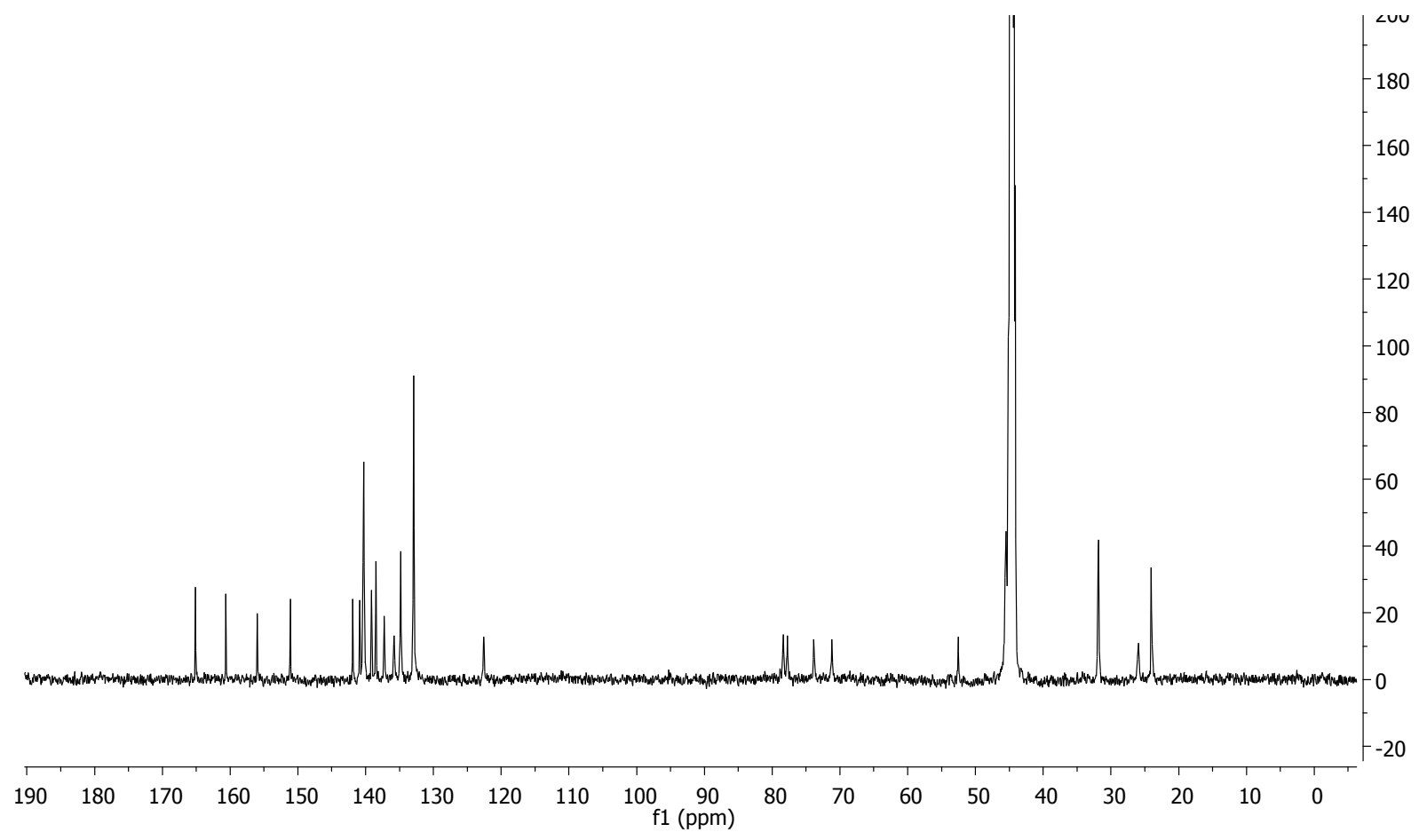




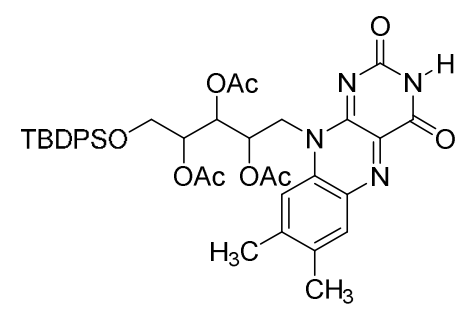

Compound 4. Compound 3 (70 $\mathrm{mg}, 0.11 \mathrm{mmol})$, and potassium carbonate $(63 \mathrm{mg}, 0.45 \mathrm{mmol})$, were suspended in DCM $(6 \mathrm{~mL})$ and then DMAP $(1 \mathrm{mg}, 0.06 \mathrm{mmol})$ was added. The mixture was cooled to 0 ${ }^{\circ} \mathrm{C}$ upon which acetic anhydride $(43 \mu \mathrm{L}, 0.45 \mathrm{mmol})$ was added. The mixture was allowed to stir at room temperature overnight. The resulting suspension was evaporated and the residue was purified by flash column chromatography $\left(\mathrm{SiO}_{2}, 5 \% \mathrm{MeOH}\right.$ in $\mathrm{DCM}$ to $100 \% \mathrm{MeOH}$ gradient) to afford compound 4 (70 mg, 83\%). ${ }^{1} \mathrm{H}$ NMR $\left(\mathrm{CDCl}_{3}\right) \delta 8.60(\mathrm{~s}, 1 \mathrm{H}), 8.03(\mathrm{~s}, 1 \mathrm{H}), 7.64(\mathrm{t}, J=5 \mathrm{~Hz}, 4 \mathrm{H}), 7.58(\mathrm{~s}, 1 \mathrm{H}), 7.44(\mathrm{~m}$, 2H), $7.40(\mathrm{t}, J=5 \mathrm{~Hz}, 4 \mathrm{H}), 5.66(\mathrm{~m}, 2 \mathrm{H}), 5.31(\mathrm{q}, J=5 \mathrm{~Hz}, 1 \mathrm{H}), 3.90-3.81(\mathrm{~m}, 2 \mathrm{H}), 3.63(\mathrm{~s}, 5 \mathrm{H}), 2.55(\mathrm{~s}$, 3H), $2.44(\mathrm{~s}, 3 \mathrm{H}), 2.29(\mathrm{~s}, 3 \mathrm{H}), 2,14(\mathrm{~s}, 3 \mathrm{H}), 1.05(\mathrm{~s}, 9 \mathrm{H}) .{ }^{13} \mathrm{C} \mathrm{NMR}\left(\mathrm{CDCl}_{3}\right) \delta 170.3,169.9,159.4$, $154.5,150.8,148.3,137.0,135.9,135.5,134.6,132.8,131.1,129.9,127.8,115.6,71.2,70.2,62.1,45.2$, 40.9, 26.6, 21.4, 21.1, 20.8, 20.3, 19.4, 19.2. ESI MS calculated $[\mathrm{M}+\mathrm{Na}]$ for $\mathrm{C}_{39} \mathrm{H}_{44} \mathrm{~N}_{4} \mathrm{NaO}_{9} \mathrm{Si} 763.3$; found 763.3 . 


\section{${ }^{1} \mathrm{H} \mathrm{NMR}\left(\mathrm{CDCl}_{3}\right)$}

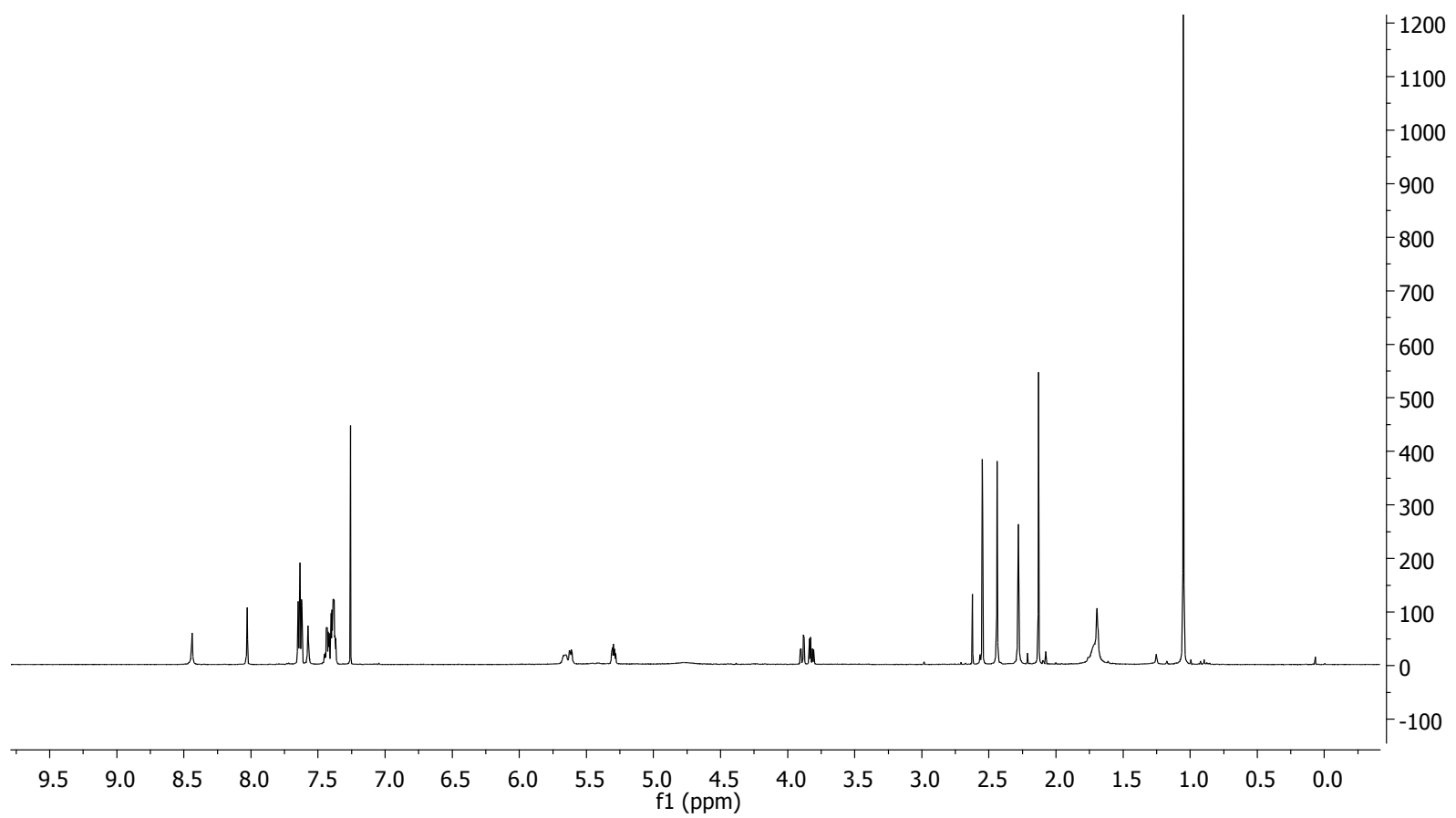

${ }^{13} \mathrm{C} \mathrm{NMR}\left(\mathrm{CDCl}_{3}\right)$

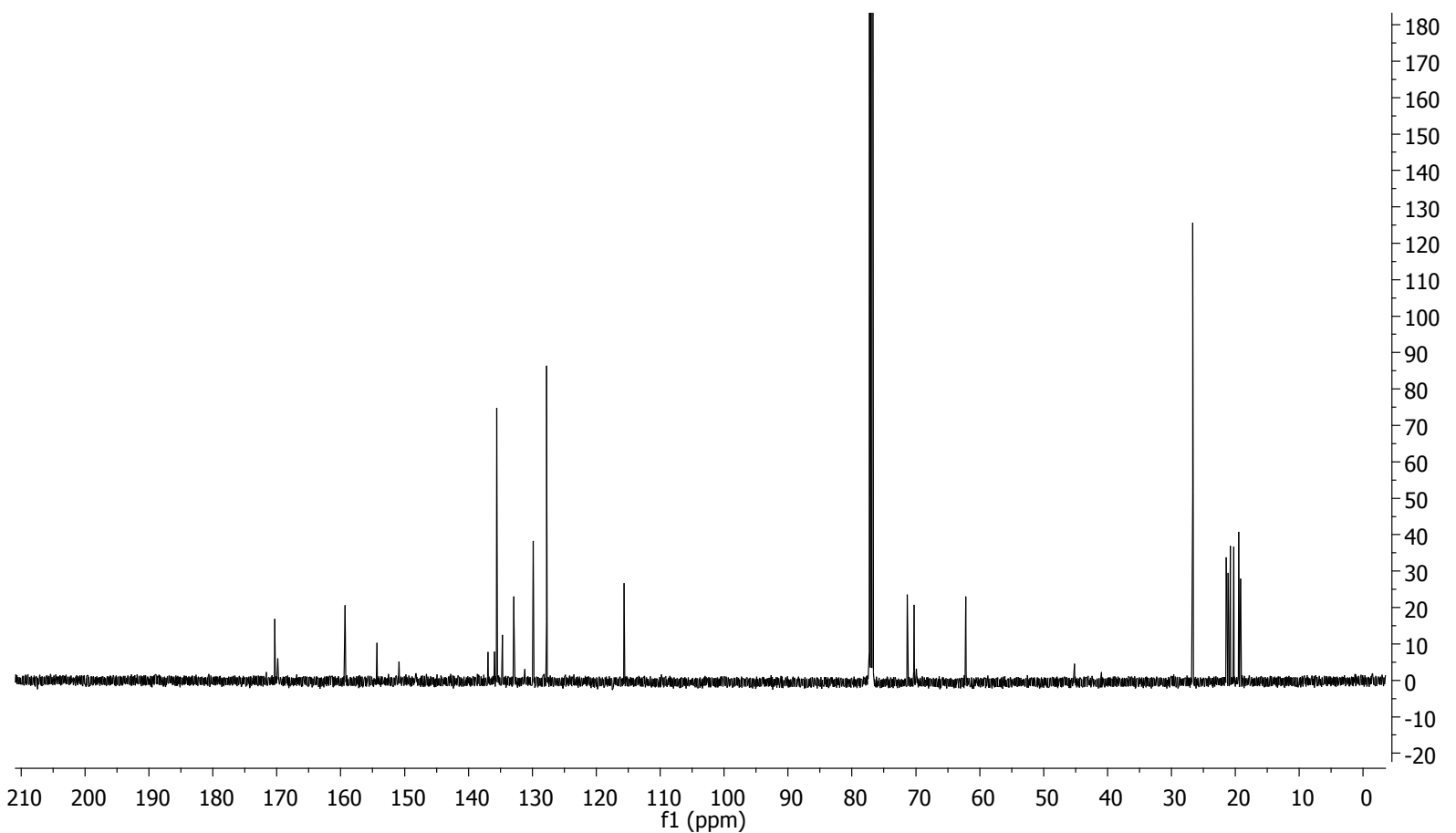




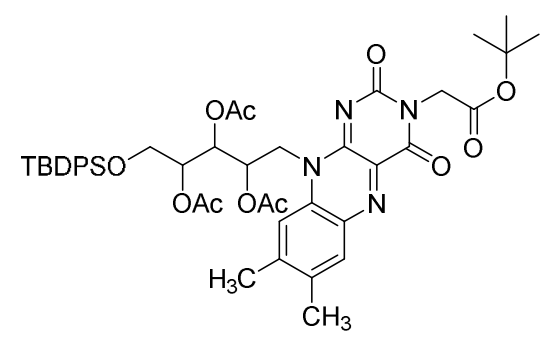

Compound 5. Compound 4 (14 mg, $22 \mu \mathrm{mol})$ was dissolved in DMF (0.5 mL) and then tert-butyl bromoacetate $(25.1 \mathrm{mg}, 26 \mu \mathrm{mol}), \mathrm{K}_{2} \mathrm{CO}_{3}(15.1 \mathrm{mg}, 0.11 \mathrm{mmol})$ were added and allowed to stir at room temperature overnight. The reaction mixture was diluted with water $(10 \mathrm{~mL})$ and then extracted with EtOAc $(3 \times 5 \mathrm{~mL})$, the combined organics was washed with water $(3 \times 10 \mathrm{~mL})$, brine $(2 \times 5 \mathrm{~mL})$ and dried over $\mathrm{Ca}_{2} \mathrm{SO}_{4}$. Evaporation of the solvents, followed by flash column chromatography $\left(\mathrm{SiO}_{2}, 5 \%\right.$ $\mathrm{MeOH}$ in DCM to $100 \% \mathrm{MeOH}$ gradient) gave compound 5 (18 mg, 93\%). ${ }^{1} \mathrm{H} \mathrm{NMR}\left(\mathrm{CDCl}_{3}\right) \delta 8.03$ (s, $1 \mathrm{H}), 7.65-7.63(\mathrm{t}, J=5 \mathrm{~Hz}, 4 \mathrm{H}), 7.58(\mathrm{~s}, 1 \mathrm{H}), 7.43(\mathrm{t}, J=5 \mathrm{~Hz}, 2 \mathrm{H}), 7.39(\mathrm{~m}, 4 \mathrm{H}), 5.65-5.61(\mathrm{dd}, J=10$, $5 \mathrm{~Hz}, 2 \mathrm{H}), 5.30(\mathrm{~m}, 1 \mathrm{H}), 4.73(\mathrm{~s}, 2 \mathrm{H}), 3.90-3.82(\mathrm{~m}, 2 \mathrm{H}), 2.98(\mathrm{~s}, 1 \mathrm{H}), 2.90(\mathrm{~s}, 1 \mathrm{H}), 2.55(\mathrm{~s}, 4 \mathrm{H}), 2.44(\mathrm{~s}$, $4 \mathrm{H}), 2.31(\mathrm{~s}, 3 \mathrm{H}), 3.14(\mathrm{~s}, 3 \mathrm{H}), 1.47(\mathrm{~s}, 9 \mathrm{H}), 1.05(\mathrm{~s}, 9 \mathrm{H}) .{ }^{13} \mathrm{C} \mathrm{NMR}\left(\mathrm{CDCl}_{3}\right) \delta 170.4,170.0,166.7$, $159.5,154.6,149.5,147.9,136.7,135.5,134.8,132.9,131.0,129.9,127.8,115.5,82.1,71.2,70.2,62.1$, 44.8, 43.5, 28.0, 26.6, 21.4, 21.1, 20.8, 20.3, 19.4, 19.2. ESI MS calculated [M+Na] for $\mathrm{C}_{45} \mathrm{H}_{54} \mathrm{~N}_{4} \mathrm{NaO}_{11} \mathrm{Si}$ 877.3; found 877.2 . 


\section{${ }^{1} \mathrm{H} \mathrm{NMR} \mathrm{CDCl}_{3}$}

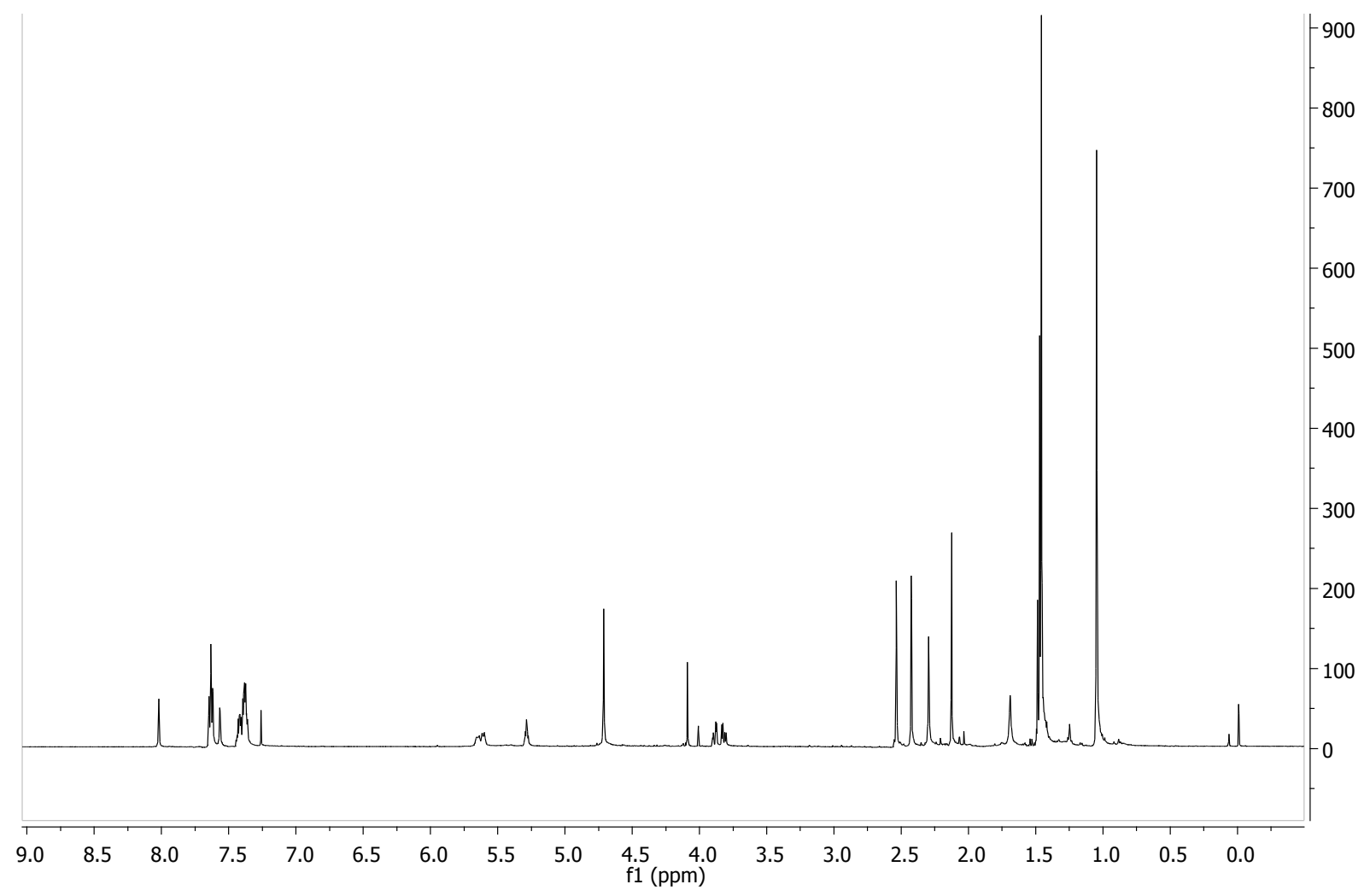

${ }^{13} \mathrm{C} \mathrm{NMR}\left(\mathrm{CDCl}_{3}\right)$

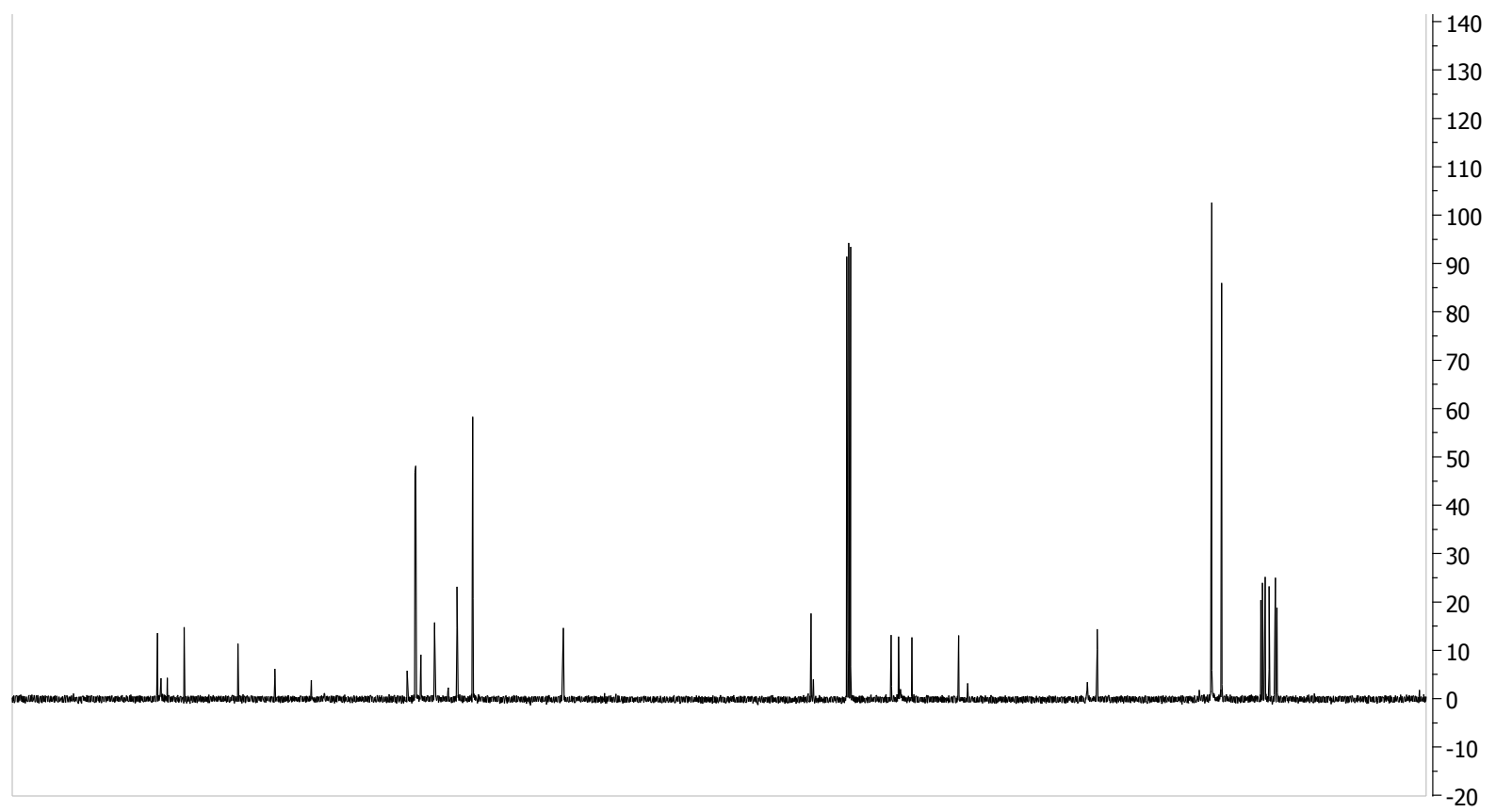




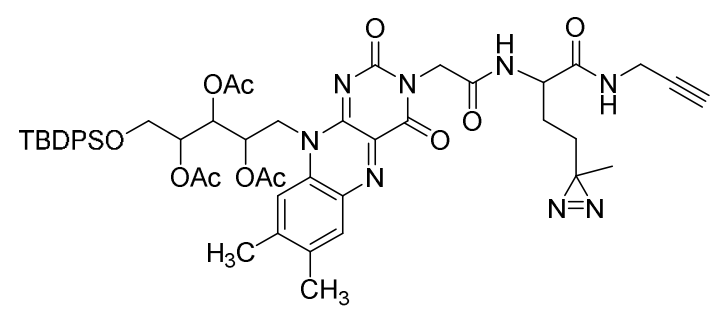

Compound 7. Compound $5(15.0 \mathrm{mg}, 17.5 \mu \mathrm{mol})$ was dissolved in $1 \mathrm{~mL}$ of $20 \%$ trifluoroacetic acid (TFA) in DCM. The solution was allowed to stir at room temperature overnight. The reaction mixture was evaporated to dryness to afford intermediate 6, which was used in the next step without purification. Intermediate 6 (13.5 mg, $17 \mu \mathrm{mol})$, EDCI $(3.9 \mathrm{mg}, 20.3 \mu \mathrm{mol})$, HOBt $(2.74 \mathrm{mg}, 20.3 \mu \mathrm{mol})$, NMM (14 $\mu \mathrm{L}, 0.13 \mathrm{mmol})$ were charged into a $10 \mathrm{~mL}$ flask and dissolved in DMF $(0.5 \mathrm{~mL})$, the resulting solution was allowed to stir at room temperature for $15 \mathrm{~min}$ and then compound $2(5.2 \mathrm{mg}, 17 \mu \mathrm{mol})$ in DMF $(0.5$ $\mathrm{mL}$ ) was added and the mixture was stirred at room temperature overnight in the dark. The reaction mixture was diluted with water $(10 \mathrm{~mL})$ and then extracted with EtOAc $(3 \times 5 \mathrm{~mL})$; the combined organics was washed with water $(3 \times 5 \mathrm{~mL}), 10 \%$ citric acid $(1 \times 5 \mathrm{~mL})$, brime $(2 \times 5 \mathrm{~mL})$ and dried over $\mathrm{Ca}_{2} \mathrm{SO}_{4}$. Evaporation of the solvents, followed by flash column chromatography $\left(\mathrm{SiO}_{2}, 5 \% \mathrm{MeOH}\right.$ in DCM to $100 \% \mathrm{MeOH}$ gradient) gave compound $7(11.5 \mathrm{mg}, 69 \%) .{ }^{1} \mathrm{H} \mathrm{NMR}\left(\mathrm{CDCl}_{3}\right) \delta 8.06(\mathrm{~s}, 1 \mathrm{H})$, 7.66-7.62 (t, $J=5 \mathrm{~Hz}, 4 \mathrm{H}), 7.60(\mathrm{~s}, 1 \mathrm{H}), 7.43(\mathrm{t}, J=5 \mathrm{~Hz}, 2 \mathrm{H}), 7.39(\mathrm{~m}, 4 \mathrm{H}), 5.65-5.61(\mathrm{~d}, J=10,5 \mathrm{~Hz}$, 1H), $5.30(\mathrm{~m}, 1 \mathrm{H}), 4.79(\mathrm{~d}, J=10 \mathrm{~Hz}, 1 \mathrm{H}), 4.70(\mathrm{~d}, J=10 \mathrm{~Hz}, 1 \mathrm{H}), 4.44(\mathrm{~m}, 1 \mathrm{H}), 4.10-4.01(\mathrm{~m}, 2 \mathrm{H}), 3.89-$ $3.85(\mathrm{~m}, 2 \mathrm{H}), 3.65(\mathrm{~s}, 2 \mathrm{H}), 2.55(\mathrm{~s}, 3 \mathrm{H}), 2.44(\mathrm{~s}, 3 \mathrm{H}), 2.35(\mathrm{t}, J=10 \mathrm{~Hz}, 3 \mathrm{H}), 2.28(\mathrm{~s}, 3 \mathrm{H}), 2.22(\mathrm{~s}, 2 \mathrm{H})$, $2.12(\mathrm{~s}, 3 \mathrm{H}), 1.25(\mathrm{~s}, 9 \mathrm{H}), 1.01(\mathrm{~s}, 3 \mathrm{H}) .{ }^{13} \mathrm{C} \mathrm{NMR}\left(\mathrm{CDCl}_{3}\right) \delta 171.2,170.6,170.3,167.5,159.7,149.5$, $148.1,136.9,135.5,135.2,132.7,131.4,129.9,127.8,82.1,72.0,71.6,70.2,68.4,62.4,52.6,44.7,44.4$, 43.0, 35.9, 29.7, 29.2, 25.7, 25.5, 22.7, 21.5, 20.8, 19.6, 19.4. ESI MS calculated [M+Na] for $\mathrm{C}_{50} \mathrm{H}_{58} \mathrm{~N}_{8} \mathrm{NaO}_{11} \mathrm{Si}$ 997.4; found 997.3. 


\section{${ }^{1} \mathrm{H} \mathrm{NMR}\left(\mathrm{CDCl}_{3}\right)$}

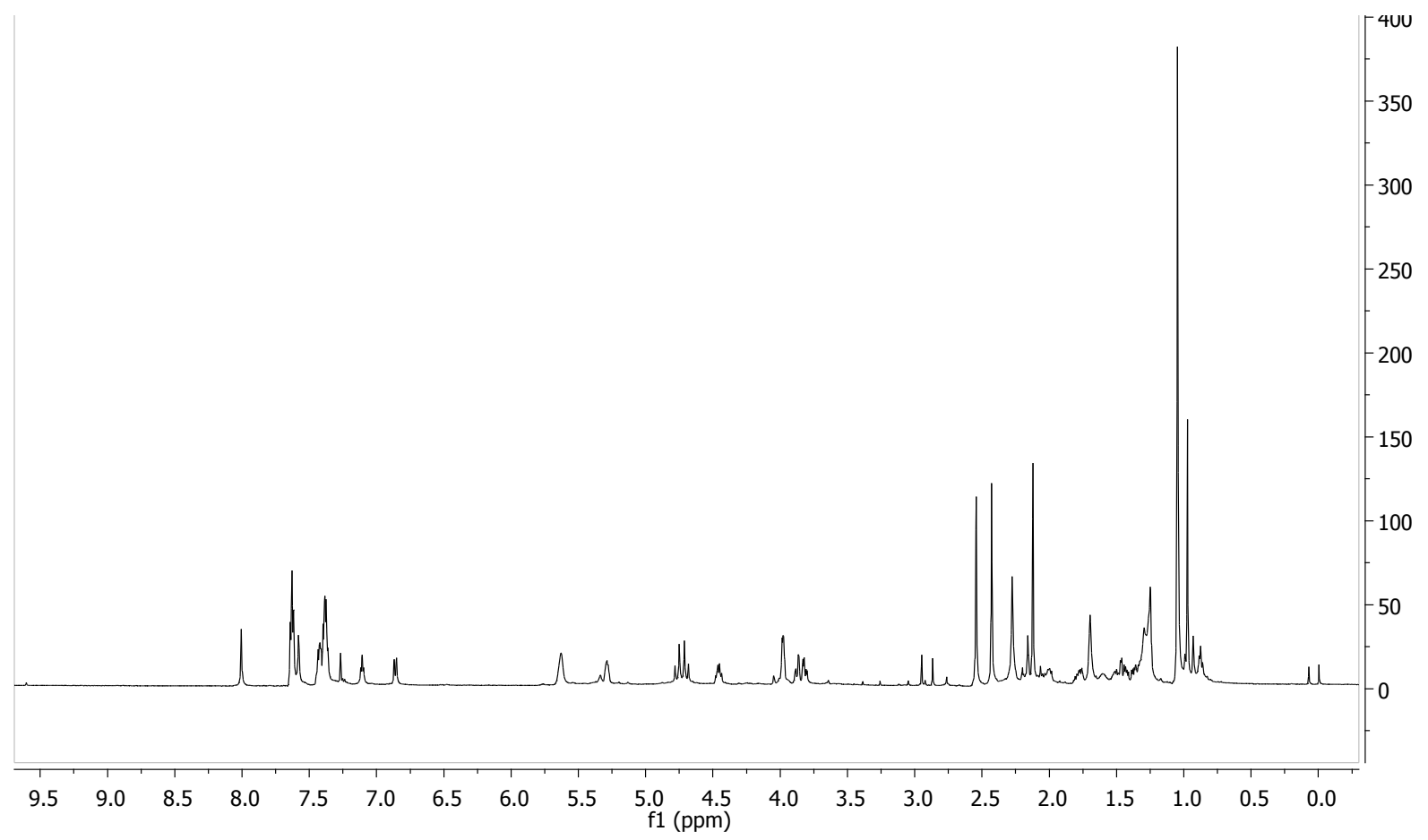

${ }^{13} \mathrm{C} \mathrm{NMR}\left(\mathrm{CDCl}_{3}\right)$

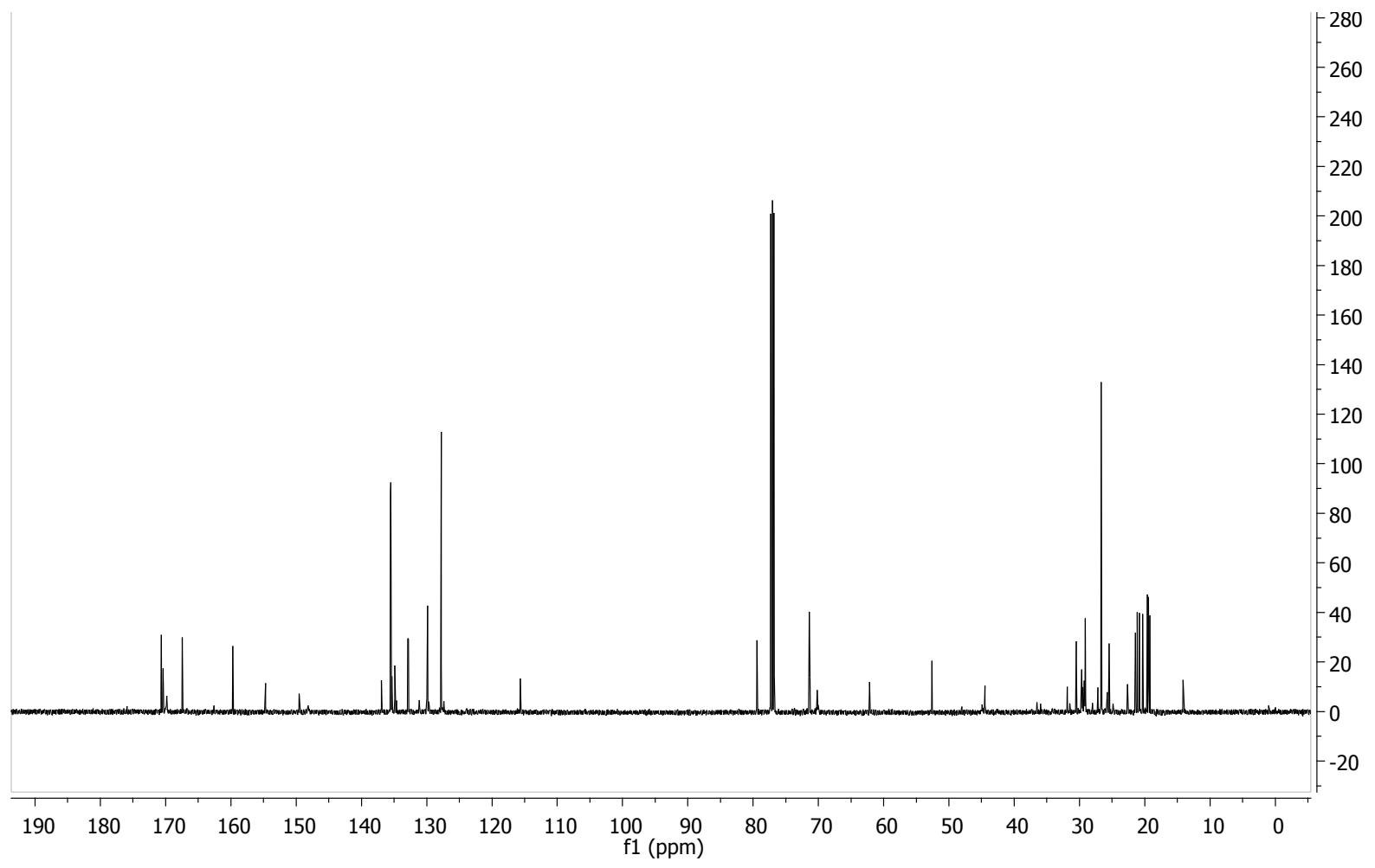




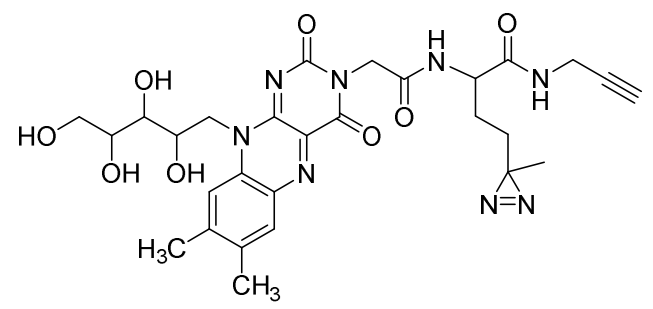

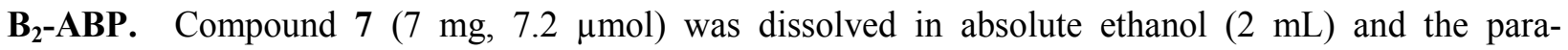
toluenesulfonic acid (PTSA) $(0.14 \mathrm{mg}, 0.72 \mu \mathrm{mol})$ was added. The resulting mixture was heated to reflux overnight and then $2 \mathrm{mg}$ of PTSA was added and allowed to reflux for 2 days. The mixture was evaporated to dryness and the residue was purified via flash column chromatography $\left(\mathrm{SiO}_{2}, 5 \% \mathrm{MeOH}\right.$ in DCM to $100 \% \mathrm{MeOH}$ gradient) to afford $\mathbf{B}_{2}-\mathbf{A B P}(3.8 \mathrm{mg}, 86 \%)$. ${ }^{1} \mathrm{H}$ NMR $\left(\mathrm{CDCl}_{3}\right) \delta\left(\mathrm{DMSO}-\mathrm{d}_{6}\right) 8.40$ $(\mathrm{t}, J=5.0 \mathrm{~Hz}, 1 \mathrm{H}), 8.31(\mathrm{~d}, J=5 \mathrm{~Hz}, 1 \mathrm{H}), 7.97(\mathrm{~s}, 2 \mathrm{H}), 5.13(\mathrm{~d}, J=5 \mathrm{~Hz}, 1 \mathrm{H}), 5.01(\mathrm{~m}, 1 \mathrm{H}), 4.89(\mathrm{~m}, 1 \mathrm{H})$, $4.81(\mathrm{~d}, J=5 \mathrm{~Hz}, 1 \mathrm{H}), 4.65(\mathrm{~m}, 1 \mathrm{H}), 4.59(\mathrm{~s}, 1 \mathrm{H}), 4,50(\mathrm{~s}, 2 \mathrm{H}), 4.28(\mathrm{~m}, 1 \mathrm{H}), 4,21(\mathrm{~m}, 1 \mathrm{H}), 3.85-3.83(\mathrm{dd}, J$ $=10,5 \mathrm{~Hz}, 2 \mathrm{H}), 3.65(\mathrm{~s}, 3 \mathrm{H}), 3.49(\mathrm{~s}, 1 \mathrm{H}), 3.45(\mathrm{~m}, 2 \mathrm{H}), 3.11(\mathrm{t}, J=5 \mathrm{~Hz}, 1 \mathrm{H}), 2.62(\mathrm{~m}, 2 \mathrm{H}), 2.41(\mathrm{~s}, 3 \mathrm{H})$, $2.35(\mathrm{~m}, 1 \mathrm{H}), 1.54-1.48(\mathrm{~m}, 2 \mathrm{H}), 1.43-1.33(\mathrm{~m}, 3 \mathrm{H}), 1.28-1.22(\mathrm{~m}, 6 \mathrm{H}), 0.98(\mathrm{~s}, 3 \mathrm{H}) .{ }^{13} \mathrm{C}$ NMR (DMSO$\left.\mathrm{d}_{6}\right) \delta 171.2,167.4,159.9,154.9,150.0,146.9,136.5,134.9,132.6,131.2,128.2,118.0,81.4,74.0,73.9$, 69.0, 63.7, 56.4, 52.1, 47.6, 43.9, 30.6, 28.4, 27.1, 26.1, 21.2, 19.8, 19.2. ESI MS calculated [M+Na] for $\mathrm{C}_{28} \mathrm{H}_{34} \mathrm{~N}_{8} \mathrm{NaO}_{8}$ 633.2; found 633.2. HRMS [M+Na] 633.238. 
${ }^{1} \mathrm{H}$ NMR (DMSO-d ${ }_{6}$ )

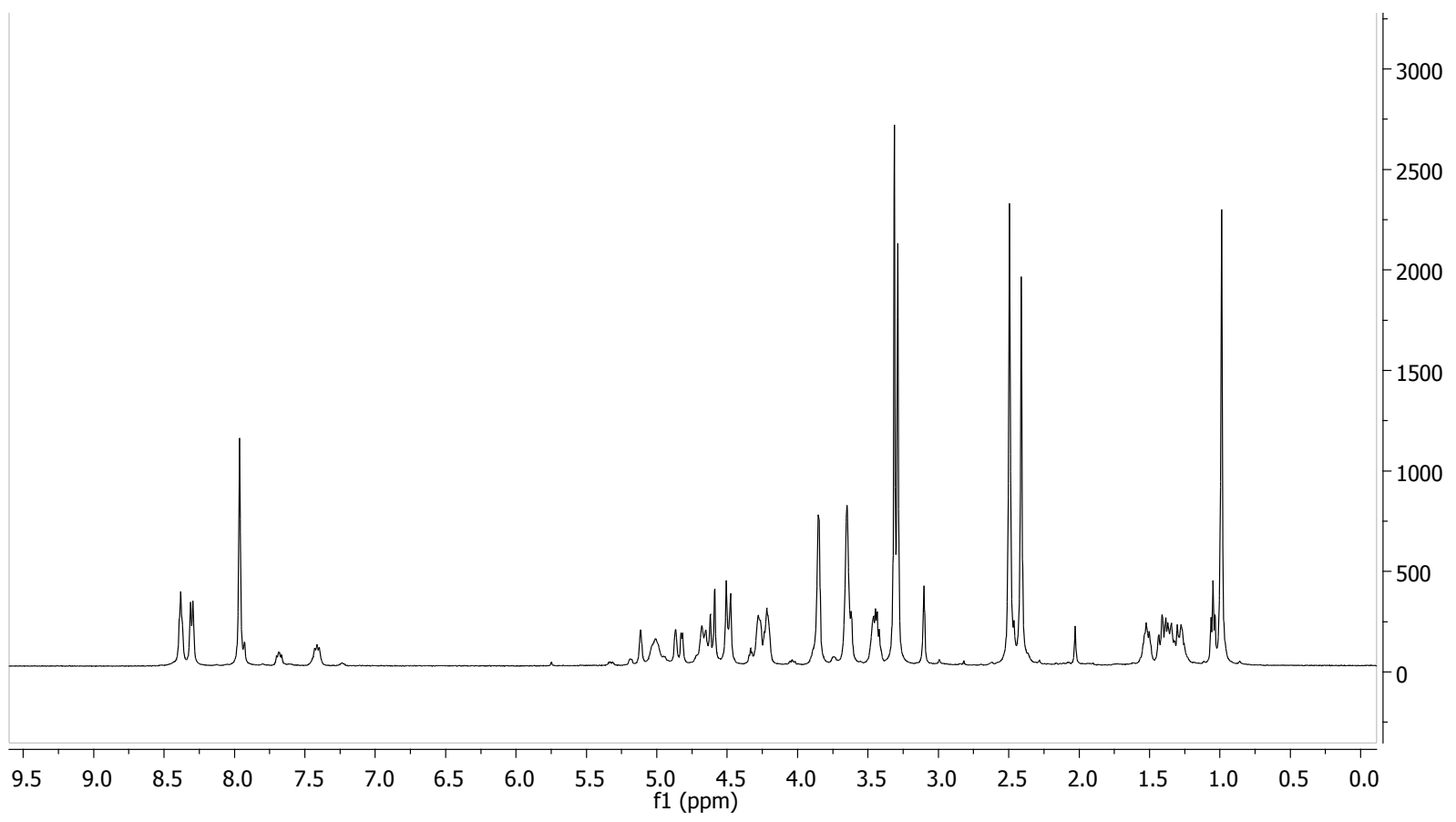

${ }^{13} \mathrm{C}$ NMR (DMSO-d ${ }_{6}$ )

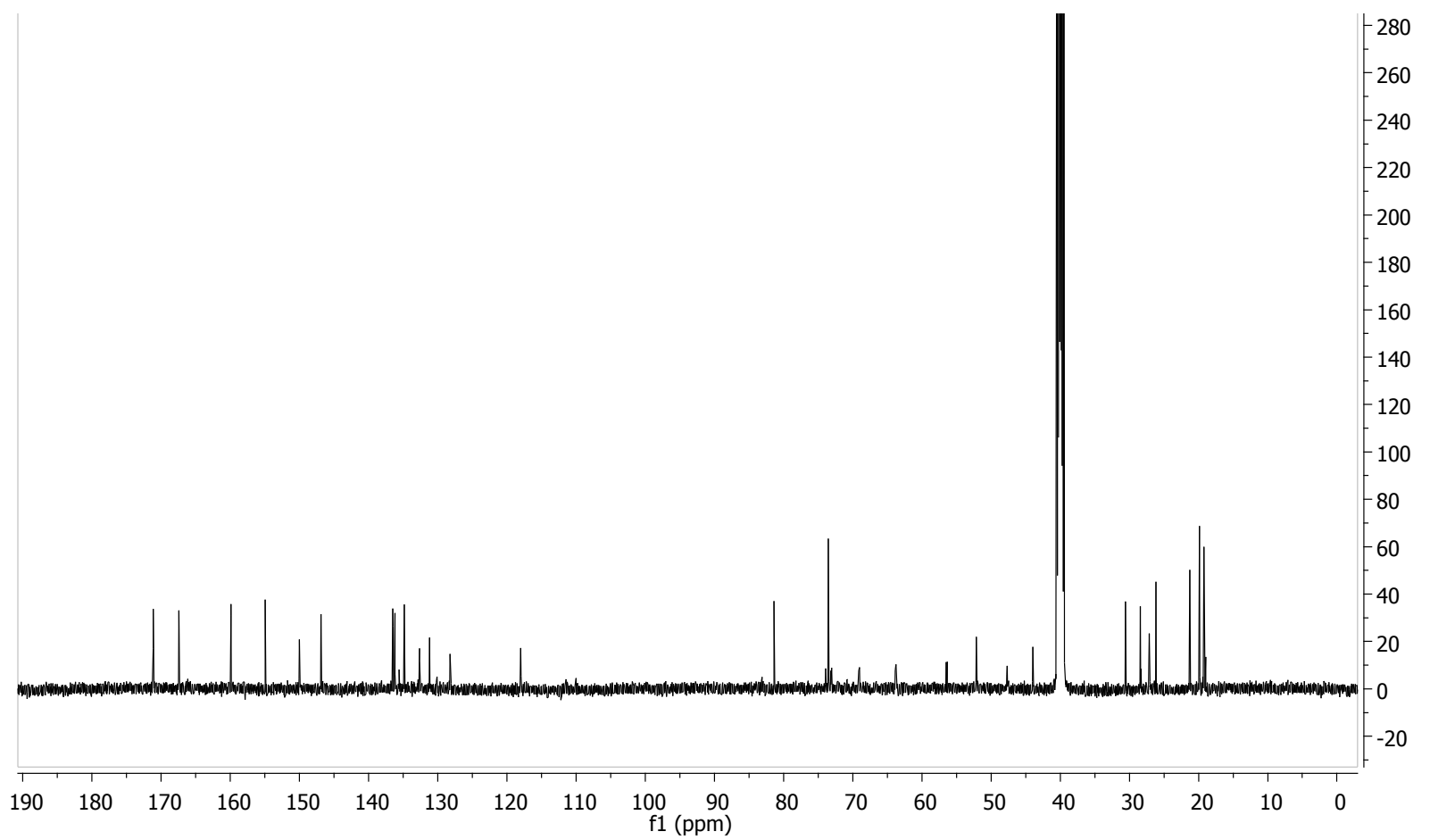




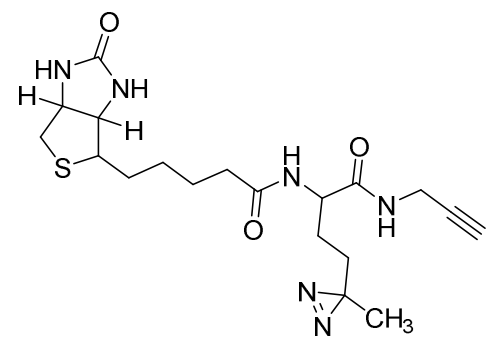

Synthesis of $\mathbf{B}_{7}$-ABP. Biotin (40 mg, $0.16 \mathrm{mmol}$ ), EDCI (37 mg, $\left.0.19 \mathrm{mmol}\right)$, HOBt (26.3 mg, 0.19 mmol), NMM (0.11 mL, $0.97 \mathrm{mmol})$ were charged into a $10 \mathrm{~mL}$ flask and dissolved in DMF (3 $\mathrm{mL})$, the resulting solution was allowed to stir at room temperature for $15 \mathrm{~min}$ and then compound $\mathbf{3}$ (50 $\mathrm{mg}$, $75 \mu \mathrm{L})$ in dissolved DMF ( $3 \mathrm{~mL}$ ) was added and the mixture was stirred at room temperature overnight in the dark. The reaction mixture was diluted with water $(15 \mathrm{~mL})$ and then extracted with EtOAc $(3 \times 10$ $\mathrm{mL})$, the combined organics was washed with water $(3 \times 10 \mathrm{~mL}), 10 \%$ citric acid $(1 \times 10 \mathrm{~mL})$, brine $(2 \times$ $10 \mathrm{~mL})$ and dried over $\mathrm{Ca}_{2} \mathrm{SO}_{4}$. Evaporation of the solvents, followed by flash chromatography $\left(\mathrm{SiO}_{2}\right.$, $5 \% \mathrm{MeOH}$ in DCM to $100 \% \mathrm{MeOH}$ gradient) gave vitamin $\mathrm{B}_{7}-\mathrm{ABP}(12 \mathrm{mg}, 15 \%) .{ }^{1} \mathrm{H} \mathrm{NMR}\left(\mathrm{CD}_{3} \mathrm{OD}\right)$ $\delta$ 4.51-4.49 (dd, $J=10,5 \mathrm{~Hz}, 1 \mathrm{H}), 4.32-4.30(\mathrm{dd}, J=10,5 \mathrm{~Hz}, 1 \mathrm{H}), 4.28-4.25(\mathrm{dd}, J=10,5 \mathrm{~Hz}, 1 \mathrm{H})$, $3.20(\mathrm{~m}, 1 \mathrm{H}), 2.95-2.89(\mathrm{~m} .2 \mathrm{H}), 2.81-2.78(\mathrm{~d}, J=10 \mathrm{~Hz}, 1 \mathrm{H}), 2.72-2.70(\mathrm{~d}, J=10 \mathrm{~Hz}, 1 \mathrm{H}), 2.61-2.59(\mathrm{t}$, $J=5 \mathrm{~Hz}, 1 \mathrm{H}), 2.30-2.24(\mathrm{~m}, 2 \mathrm{H}), 1.75-1.58(\mathrm{~m}, 5 \mathrm{H}), 1.53-1.29 \quad(\mathrm{~m}, 6 \mathrm{H}), 1.00(\mathrm{~s}, 3 \mathrm{H}) .{ }^{13} \mathrm{C}$ NMR $\left(\mathrm{CD}_{3} \mathrm{OD}\right) \delta 176.1,173.6,166.1,74.1,72.3,63.4,61.7,57.1,54.1,51.3,43.9,41.0,36.3,31.8,29.5,27.7$, 26.6, 26.2, 19.7. ESI MS calculated [M+Na] for $\mathrm{C}_{19} \mathrm{H}_{28} \mathrm{~N}_{6} \mathrm{NaO}_{3} \mathrm{~S}$ 443.2; found 443.0. HRMS [M+Na] 443.181. 


\section{${ }^{1} \mathrm{H}$ NMR $\mathrm{CD}_{3} \mathrm{OD}$}

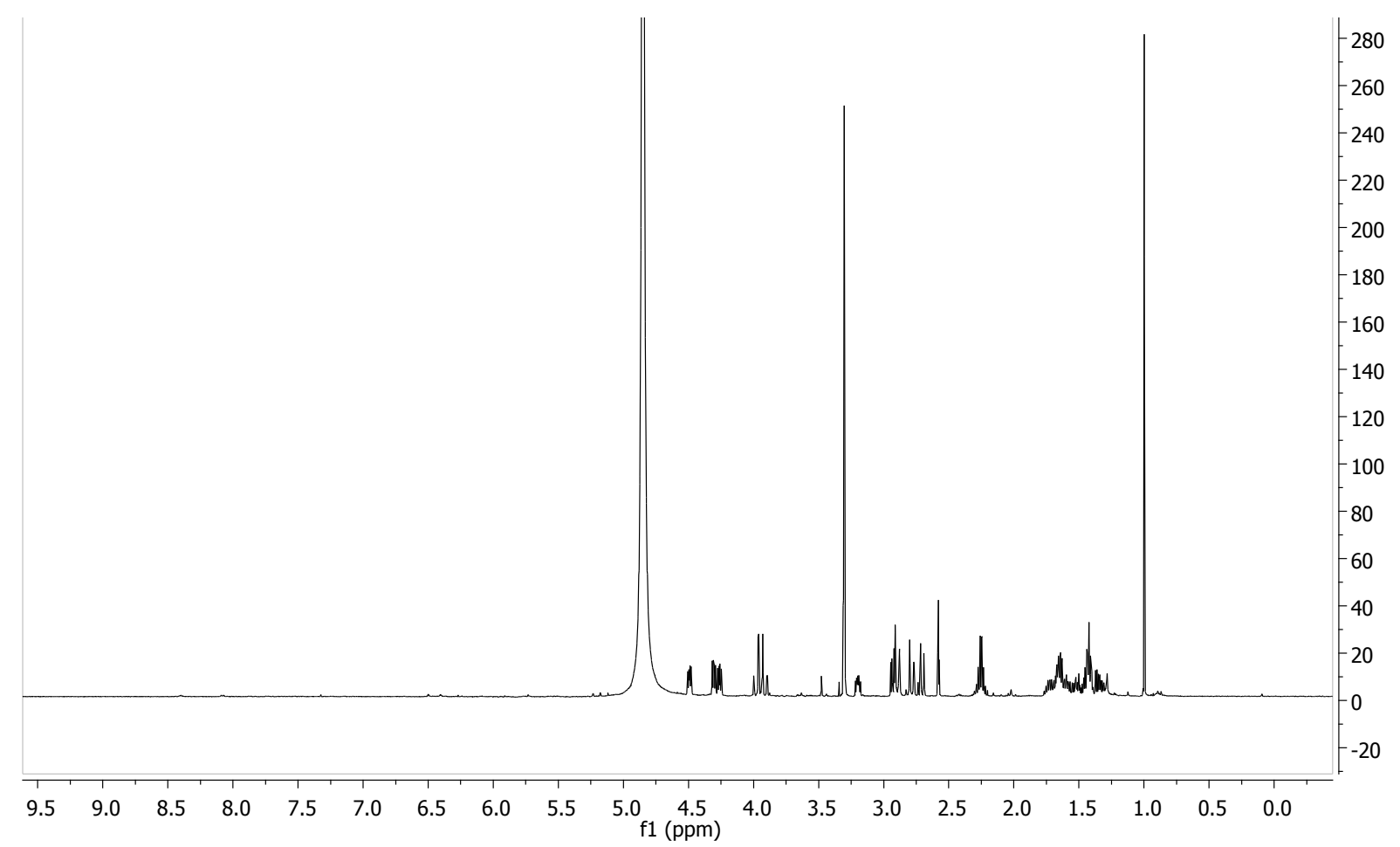

${ }^{13} \mathrm{C}$ NMR $\mathrm{CD}_{3} \mathrm{OD}$

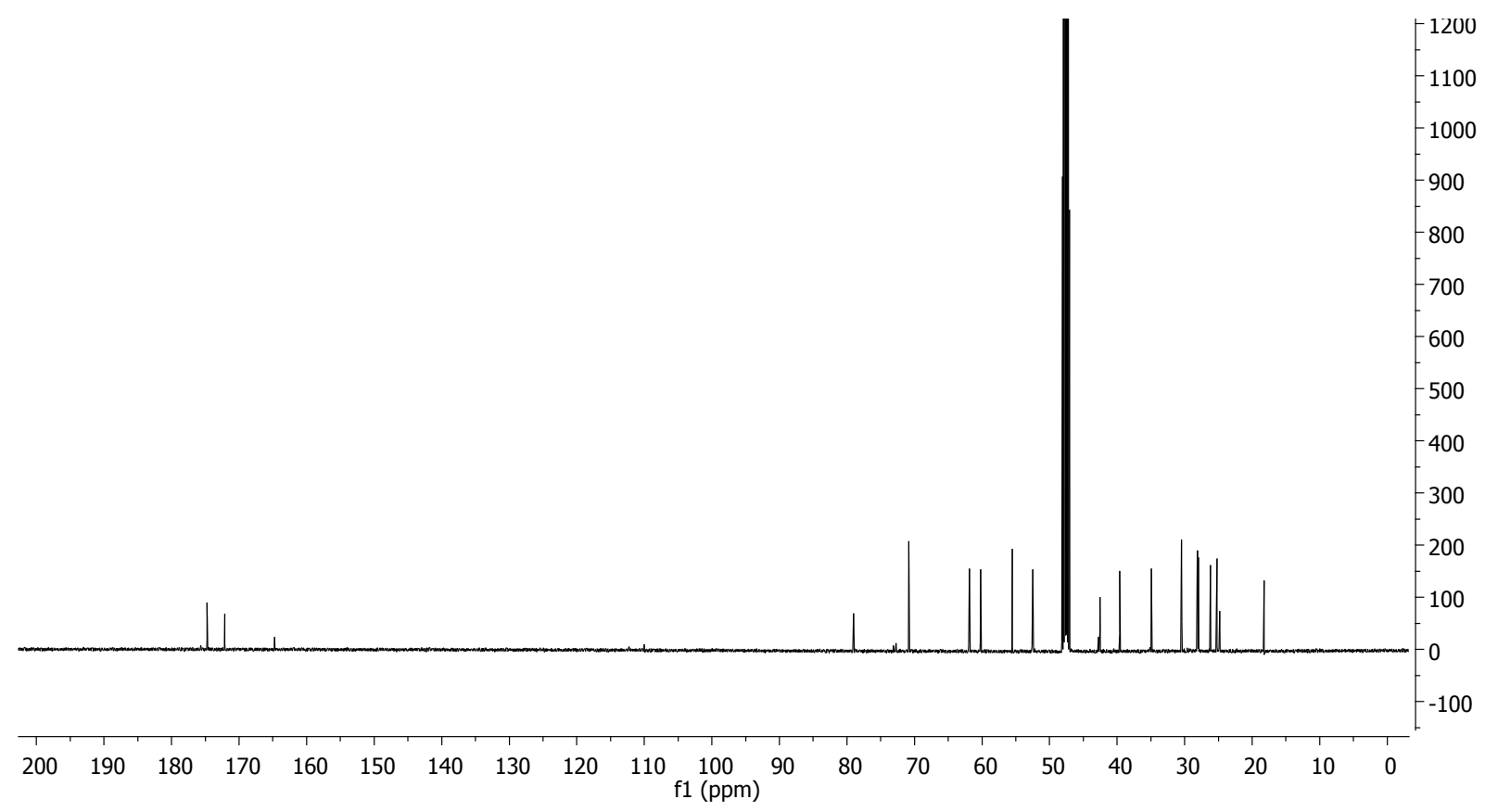


Bacteria Culture Conditions. Chloroflexus aurantiacus J-10-fl, provided by Professor Don Bryant's laboratory at Penn State University, was routinely maintained on a medium based on BG-11 basal medium, ${ }^{2}$ in which the sodium nitrate $(17.6 \mathrm{mM})$ was replaced by $\mathrm{NaCl}(17.6 \mathrm{mM})$, unless indicated otherwise, and $\mathrm{NH}_{4} \mathrm{Cl}(10.0 \mathrm{mM})$ was added as inorganic nitrogen source. The medium was buffered using TES $\left(10 \mathrm{mM}, \mathrm{pH}\right.$ 8). Unless indicated otherwise, $\mathrm{NaHCO}_{3}(2.2 \mathrm{mM})$ was added as inorganic carbon source. For organic carbon, the cultures were provided with either $0.15 \%$ yeast extract (YE) (Difco) or $0.3 \%$ vitamin-assay grade casamino acids (Becton Dickinson, Sparks, MD). Unless indicated otherwise, when grown on casamino acids (CAs), the cultures were provided with a vitamin mixture based on $\mathrm{PE}^{3}$, with the addition of riboflavin $(0.13 \mu \mathrm{M}$, based on Wolfe's vitamins $)$, referred to as "replete" vitamins.

Cultures were inoculated into medium $\left(52^{\circ} \mathrm{C}\right)$, at a density of $\sim 0.5-2.0 \%$ from stationary-phase, anoxic, phototrophic cultures, in serum bottles. Test cultures were grown on a rocking shaker (Thermo

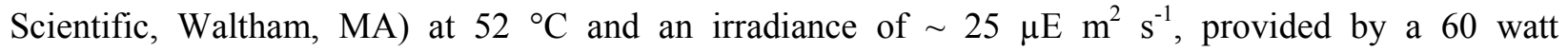
incandescent bulb. Cultures were inoculated into aerobic media to allow the cells to go through both aerobic chemoheterotrophic growth and anoxic, photoheterotrophic growth. Growth of biomass was monitored over time by subsampling and analyzing the optical density $(650 \mathrm{~nm})$. Pigment development was monitored by measuring absorbance: $430 \mathrm{~nm}$ - carotenoid peak indicative of aerobic growth; $740 \mathrm{~nm}$ - chlorophyll peak indicative of anaerobic, phototrophic growth. Cultures grown on $0.3 \%$ CAs with vitamins (Wolfe's) grew to similar densities as cultures grown on $0.15 \% \mathrm{YE}$, but growth was slower. Cultures approached stationary phase approximately three to four days after inoculation. Cultures grown on $0.15 \%$ YE were unaffected by the addition of vitamins (Wolfe's) over several transfers (data not shown).

To determine the salvage requirements of $C$. aurantiacus $J-10-f l$ for thiamine $\left(\mathrm{B}_{1}\right)$, riboflavin $\left(B_{2}\right)$, and biotin $\left(B_{7}\right)$, cultures were grown on $0.15 \%$ YE without additional vitamins, and were then transferred to $0.3 \%$ CAs with the replete vitamin mix lacking $B_{1}, B_{2}$, or $B_{7}$. Cultures deprived of $B_{1}\left(B_{1}\right.$ limited) showed diminished growth on the first transfer from $0.15 \%$ YE, while the other treatments $\left(B_{2}\right.$ 
and $\mathrm{B}_{7}$ limited) were unaffected. ${ }^{4}$ However, on a second transfer, cultures limited of $\mathrm{B}_{7}$ failed to grow, while the $\mathrm{B}_{2}$ limited culture remained unaffected. In addition, when the $\mathrm{B}_{1}$ limited and affected culture from the first transfer was transferred back to replete medium, the culture grew as well as the culture growing on the replete vitamins during both transfers. Cultures limited of $\mathrm{B}_{2}$ were unaffected through three transfers from replete medium.

Based on these results, a second experiment was designed for mass space analysis. For this experiment, starter cultures were grown on $0.3 \%$ vitamin-assay casamino acids $(\mathrm{CAs})+$ the replete vitamin mix ( i.e., PE vitamins $+\mathrm{B}_{2}$ ) to stationary phase $(\mathrm{OD} \sim 1.6-2.0)$ at a volume of $\sim 120 \mathrm{~mL}$ in serum bottle $(120 \mathrm{~mL}$, in duplicate). The cultures were then centrifuged at $8,000 \times g(\mathrm{rt}, 5 \mathrm{~min})$ in $50 \mathrm{~mL}$ Falcon tubes and then resuspended in deoxygenated BG-11 with $0.3 \%$ CA but with no added vitamins. Cultures were resuspended in $\sim 60 \mathrm{~mL}$ of medium so that $\mathrm{OD}(650 \mathrm{~nm})$ was $\sim 2 \times$ that of culture, or $\sim 4.0$. To prepare thiamine limited cells $\left(-\mathrm{B}_{1}\right)$, this starter culture was used to inoculate one each of three serum bottles of BG-11 (120 mL, prewarmed to $52{ }^{\circ} \mathrm{C}$, but not degassed) with $0.3 \% \mathrm{CA}$ and with the replete vitamin mix but excluding thiamine $\left(-\mathrm{B}_{1}\right)$ to initial $\mathrm{OD}$ values of $\sim 0.1, \sim 0.25$, and $\sim 0.5(650 \mathrm{~nm})$. The OD $(650 \mathrm{~nm})$ values of the cultures were monitored over time, by subsampling with an $\mathrm{N}_{2}$-degassed syringe and needle, and the cultures were terminated. To prepare biotin limited cells (- $\left.\mathrm{B}_{7}\right)$, inoculum (2.4 $\mathrm{mL})$ from the starter culture above was used to inoculate one serum bottle $(120 \mathrm{~mL})$ of $0.3 \%$ CA BG-11 plus the replete vitamin mix excluding biotin $\left(-\mathrm{B}_{7}\right)$ to an initial OD of $\sim 0.08(650 \mathrm{~nm})$ and was grown to maximum OD of $\sim 2.0-3.0(650 \mathrm{~nm})$. This limited biotin culture was used to inoculate (without pelleting) three serum bottles $(120 \mathrm{~mL})$ of BG-11 with $0.3 \%$ CA plus replete vitamin mix excluding biotin $\left(-B_{7}\right)$ at initial OD values of $0.1,0.25$, and $0.5(650 \mathrm{~nm})$, as for the $-\mathrm{B}_{1}$ treatment above. The OD values $(650 \mathrm{~nm})$ of the cultures were monitored as the $-\mathrm{B}_{1}$ treatment above, and the cultures were terminated when the OD values $(650 \mathrm{~nm})$ did not change in a 12-24 h period. For riboflavin cultures, since in the previous experiment growth was not affected by $\mathrm{B}_{2}$ limitation, Chloroflexus aurantiacus $J$ 10- $f l$ was grown in $\mathrm{B}_{2}$ limited media and then transferred to replete media. To prepare cells for $\mathrm{B}_{2}$ studies, cells were grown in replete medium, washed with an equal volume of vitamin-free medium, and 
was used to inoculate $(2.4 \mathrm{~mL})$ one serum bottle $(120 \mathrm{~mL})$ of $0.3 \%$ CA plus replete vitamin mix lacking riboflavin $\left(-\mathrm{B}_{2}\right)$ and grown to maximum density of $\sim 1.8-2.0(650 \mathrm{~nm})$. This riboflavin-limited culture was used to inoculate two serum bottles $(120 \mathrm{~mL})$ to initial OD values of 0.25 and $0.50(650 \mathrm{~nm})$. The culture OD values were monitored as above, terminating cultures after two to three doublings and an OD of $\sim 1.0-2.0(650 \mathrm{~nm})$. Limited cultures, once reached optimal OD, were used for subsequent probe labeling and mass spec analyses.

Cloning and Purification. The Rcas_0667 (Roseiflexus castenholzii DSM 13941, ThiY) gene encoding the periplasmic binding component of the ABC-type hydroxymethylpyrimidine uptake system was PCRamplified from genomic DNA and joined to an N-terminal hexahistidine tag in an E. coli cytoplasmic expression vector. ${ }^{5}$ The sequence fragment for cloning of the Tter_0402 (Thermobaculum terrenum ATCC BAA-798, RibY) gene encoding the periplasmic binding component of the ABC-type riboflavin uptake system was obtained by gene synthesis (Integrated DNA Technologies [IDT], Coralville, IA). Signal peptide sequences, identified using SignalP, ${ }^{6}$ were excluded from the cloned region so that only the predicted mature protein would be expressed. Primers were designed using a high-throughput primer design $\operatorname{tool}^{7}$ and ordered from IDT (Coralville, IA). All constructs were sequenced to verify correct insertion of the coding region. Proteins from $500 \mathrm{~mL}$ E. coli expression cultures were purified by affinity chromatography with NiNTA beads and eluted with $250 \mathrm{mM}$ imidazole using benchtop or automated purification protocols as previously described. ${ }^{8}$ Eluates were exchanged into final buffer (100 $\mathrm{mM}$ HEPES, $150 \mathrm{mM} \mathrm{NaCl}, \mathrm{pH}$ 7.5) with a desalting column or dialysis and frozen in liquid nitrogen for storage. Samples were greater than $80 \%$ pure as estimated by Coomassie stained SDS-PAGE gels.

Fluorescent Gel Imaging of Purified Proteins. To assess the specificity of probes to desired targets, purified proteins known to bind $\mathrm{B}_{1}$ (ThiY, Rcas_0667), B 2 (RibY, Tter_0402), and B (Streptavidin (GBiosciences)) were tested. The concentrations of protein samples were normalized $(5 \mu \mathrm{M})$ and labeled with corresponding B vitamin ABP. Proteins $(5 \mu \mathrm{M})$ were incubated with individual ABPs at $37^{\circ} \mathrm{C}$ for 1 
$\mathrm{h}$, with gently agitation in the dark, followed immediately by UV irradiation on ice for $7 \mathrm{~min}(365 \mathrm{~nm}, 10$ $\mathrm{cm}$ ). To prepare samples for fluorescent gel analysis, we first performed click chemistry mediated attachment of an azido-tetramethylrhodamine fluorophore $(2.65 \mu \mathrm{M})$ to probe-labeled proteins followed by the addition of (tris(2-carboxyethyl)phosphine) $(22 \mu \mathrm{M})$, TBTA (Tris[(1-benzyl-1H-1,2,3-traizol-4yl)methyl])amine) in a $4: 1$ solution t-butanol:DMSO $(44.8 \mu \mathrm{M})$, copper sulfate $(45 \mu \mathrm{M})$, and proteins were separated using 10\% Tris-Glycine SDS-PAGE gels. To determine the optimum concentration of probe for testing target specificity protein samples $(5 \mu \mathrm{M})$ were labeled with corresponding B vitamin $\mathrm{ABP}(1,5$, and $20 \mu \mathrm{M})$ (Figure 3). Using the established optimal probe concentration from Figure 3, each protein was labeled in the presence of increasing concentrations $(0,1,5,25,50$, and $100 \mu \mathrm{M})$ of the corresponding native vitamin to assess quenching of fluorescent signal due to competition by the native vitamin for active site on the protein (Figure 4). The specificity of $\mathbf{B}_{\mathbf{1}}$ and $\mathbf{B}_{\mathbf{2}}$ probes was tested by evaluating probe $(20 \mu \mathrm{M})$ binding to the $\mathrm{B}_{2}$ and $\mathrm{B}_{1}$ binding proteins $(5 \mu \mathrm{M})$, respectively (Figures $6 \mathrm{~A}$ and 6B). Binding specificities for $\mathbf{B}_{\mathbf{1}}-\mathbf{A B P}$ and $\mathbf{B}_{2}-\mathbf{A B P}$ on the $\mathbf{B}_{1}$-binding protein (ThiY, Rcas_0667) appeared to favor both probes. To test competitive selectivity for $\mathbf{B}_{\mathbf{1}}-\mathbf{A B P}$ and $\mathbf{B}_{2}$-ABP on $\mathbf{B}_{1}$-binding protein (ThiY, Rcas_0667), samples were labeled with individual probe $(20 \mu \mathrm{M})$ and inhibited by individual competing native vitamin $(0,5,25,50$, and $100 \mu \mathrm{M})$ (Figures $6 \mathrm{C}$ and $6 \mathrm{D})$. To test selective competition of vitamin-limited lysates $(25 \mu \mathrm{g})$ for vitamin ABPs, corresponding pure proteins were doped into cell lysates at increasing amounts $(1 \mu \mathrm{M}, 3 \mu \mathrm{M}, 4 \mu \mathrm{M}$, and $5 \mathrm{M})$ and labeled for $30 \mathrm{~min}$. For structural integrity studies of ABP binding, heat shock control samples were denatured at $95{ }^{\circ} \mathrm{C}$ for 10 min prior to labeling.

In vitro $\mathbf{B}_{7}$-ABP Labeling and LC-MS Preparation. For biotin limited, C. aurantiacus $J$-10-fl cells (40 $\mathrm{mL}$ ) were collected from a serum bottle, spun down at $6,000 \times \mathrm{g}$ for $10 \mathrm{~min}$ at $\mathrm{rt}$ and gently resuspended in vitamin free BG-11 growth medium $(5 \mathrm{~mL})$, and an OD $(650 \mathrm{~nm})$ was determined for each culture. Cell stocks were then spun down at $6,000 \times g$ for $10 \mathrm{~min}$ at $4{ }^{\circ} \mathrm{C}$ and washed twice in Tris- $\mathrm{HCl}$ buffer $(0.2 \mathrm{M}$, $\mathrm{pH}$ 8), fractionated and lysed. Lysate was treated using three different labeling conditions based upon 
molar ratios: probe only (PO, 1:4 protein to probe), no probe DMSO control (NP, 1:4 protein to DMSO), and no probe with no DMSO and no click chemistry (NPnoCC) were incubated for $10 \mathrm{~min}$ at $52{ }^{\circ} \mathrm{C}, 400$ rpm on shaker block in screw top Axygen tubes $(1.5 \mathrm{~mL})$. Immediately following labeling, samples were spun down and transferred to 6-well tissue culture plates and UV irradiated (on ice for $7 \mathrm{~min}, 10 \mathrm{~cm}$ ). After irradiation, samples were transferred back into Axygen tubes $(1.5 \mathrm{~mL})$ for click chemistry. Click reagents were added in order and calculated based upon the final molar concentration of probe in each individual sample: 1:4 Biotin-azide (probe to biotin-azide), 1:8.3tris([2-carboxyethyl]phosphine) ((TCEP) biotin azide to TCEP), 1:1.7 tris[(1-benzyl-1H-1,2,3-triazol-4-yl)methyl]amine in a 4:1 solution $\mathrm{t}$ butanol:DMSO ((ligand) biotin-azide to ligand), and 1:17 $\mathrm{CuSO}_{4}$ (biotin azide to $\mathrm{CuSO}_{4}$ ). For example, given a recovered amount of $1.10 \mathrm{e}^{-9}$ moles of protein (with an estimated $4.40 \mathrm{e}^{-9}$ moles probe) for my $\mathrm{B}_{1}$ limited PO sample, then $8.80 \mathrm{e}^{-9}$ moles biotin-azide $(0.88 \mu \mathrm{L}, 10 \mathrm{mM})$ was added, followed by $7.30 \mathrm{e}^{-8}$ moles TCEP $(2.92 \mu \mathrm{L}, 25 \mathrm{mM}), 1.50 \mathrm{e}^{-8}$ moles ligand $(1.50 \mu \mathrm{L}, 10 \mathrm{mM})$, and $1.50 \mathrm{e}^{-7} \mathrm{CuSO}_{4}(2.99 \mu \mathrm{L}, 50$ $\mathrm{mM}$ ). Samples were vortexed and incubated in the dark at $\mathrm{rt}$ for $1.5 \mathrm{~h}$. Next, samples were washed using Amicon $3.0 \mathrm{kDa}$ centrifugal filter devices (Millipore) and resuspended in 1.2\% SDS (0.5 mL), heated for $2.0 \mathrm{~min}$ at $95{ }^{\circ} \mathrm{C}$ and probe sonicated. Samples were normalized per condition and enriched. For enrichment of ABP-labeled proteins, based on recovered protein, an aliquot (30-100 $\mu \mathrm{L})$ of streptavidin agarose resin (Thermo Fisher), per prepared sample, was placed in a BioRad Bio-Spin Chromatography Column using a vacuum manifold. The resin was washed with PBS $(3 \times 3.0 \mathrm{~mL})$ and transferred to a vial (4.0 mL) using three aliquots of PBS $(0.5 \mathrm{~mL})$. Additional PBS $(1.0 \mathrm{~mL})$ was added to each tube followed by the normalized proteome sample. Each falcon tube contained a final SDS concentration of $0.2 \%$. Tubes were then rotated for $4 \mathrm{~h}$ at $37^{\circ} \mathrm{C}$. Following streptavidin capture of probe-labeled proteins, each sample containing resin solution was transferred into a Bio-Spin column on the vacuum manifold. The resin was washed with $0.5 \%$ SDS in PBS $(3 \times 1.0 \mathrm{~mL}), 6.0 \mathrm{M}$ urea in PBS $(3 \times 1.0 \mathrm{~mL})$, MilliQ water $(3 \times 1.0 \mathrm{~mL})$, and PBS $(5 \times 1.0 \mathrm{~mL})$. The resin was then transferred to sterile tubes $(1.5 \mathrm{~mL})$ using two aliquots of ammonium bicarbonate $(0.5 \mathrm{~mL}, 25 \mathrm{mM}, \mathrm{pH} 8)$, and the was supernatant discarded. To obtain peptides for MS analysis, an aliquot of $\mathrm{NH}_{4} \mathrm{HCO}_{3}(0.2 \mathrm{~mL}, 25 \mathrm{mM}, \mathrm{pH} 8)$ was added to the resin 
for each sample and treated with a trypsin solution (1-2 $\mu \mathrm{L}$, trypsin was reconstituted in $180 \mu \mathrm{L}$ of $\mathrm{NH}_{4} \mathrm{HCO}_{3}$ ). Resin solutions were heated at $37^{\circ} \mathrm{C}$ for $15 \mathrm{~h}$ with agitation. Following trypsin digestion, supernatant was collected by centrifugation at $10,500 \times g$ and placed in a sterile tube. An additional amount of $\mathrm{NH}_{4} \mathrm{HCO}_{3}(0.15 \mathrm{~mL})$ was added to sample resin and agitated on a thermal mixer at $37{ }^{\circ} \mathrm{C}$ for 10 min. Supernatants were again collected at $10,500 \times g$ and added to corresponding tubes from prior collection. Volatiles were removed from tryptic peptide solutions by speedvac concentrator, and peptides were reconstituted in $\mathrm{NH}_{4} \mathrm{HCO}_{3}\left(30 \mu \mathrm{L}\right.$, and heated for 10 min at $37{ }^{\circ} \mathrm{C}$ with mild agitation. Samples were centrifuged in a Beckman TLA 120.1 rotor $\left(122,000 \times g, 20\right.$ min at $\left.4{ }^{\circ} \mathrm{C}\right)$ and placed in vials $(25 \mu \mathrm{L}$ aliquots) for subsequent MS analysis.

In vivo Probe Labeling and LC-MS Preparation. Chloroflexus aurantiacus $J-10-f l$ cells $(20 \mathrm{~mL})$ were spun down at $6,000 \times g$ for $10 \mathrm{~min}$ at $\mathrm{rt}$ and gently resuspended in pre-warmed vitamin free BG-11 growth medium $(5 \mathrm{~mL})$ and the resulting cell density $(650 \mathrm{~nm})$ was determined prior to labeling (Figure S4). After confirming cultures were still in log phase growth by OD measurement, sample stocks were aliquoted into 6-well tissue culture plates for labeling. Labeling consisted using three different labeling conditions based upon molar ratios: probe only (PO, 1:4 protein to probe), no probe DMSO control (NP, 1:4 protein to DMSO), and no probe with no DMSO and no click chemistry (NPnoCC) were incubated in a rocking shaker (Thermo Scientific, Waltham, MA) for $10 \mathrm{~min}$ at $52{ }^{\circ} \mathrm{C}\left(\sim 25 \mu \mathrm{E} \mathrm{m} \mathrm{m}^{-2} \mathrm{~s}^{-1}, 60-\mathrm{W}\right)$. Immediately following labeling, samples were UV irradiated on ice for 7 min $(10 \mathrm{~cm})$. After irradiation, samples were transferred into Axygen tubes $(1.5 \mathrm{~mL})$ and washed with Tris-HCL buffer $(0.2 \mathrm{M}$, pH 8$)$ twice at $6,000 \times \mathrm{g}$ for $10 \mathrm{~min}$ at $4{ }^{\circ} \mathrm{C}$, fractionated, lysed, and subjected to click chemistry. Click reagents were added at concentrations based upon the final molar concentration (probe to biotin-azide, biotin-azide to reagents) of each individual sample and order as follows: 1:4 Biotin-azide (probe to biotin-azide), 1:8.3 tris([2-carboxyethyl]phosphine) ((TCEP) biotin-azide to TCEP), 1:1.7 tris[(1-benzyl-1H-1,2,3-triazol-4yl)methyl]amine in a 4:1 solution t-butanol:DMSO ((ligand) biotin-azide to ligand), and 1:17 $\mathrm{CuSO}_{4}$ (biotin-azide to $\mathrm{CuSO}_{4}$ ). Samples were vortexed and incubated in the dark at $\mathrm{rt}$ for $1.5 \mathrm{~h}$. Next, samples 
were washed using a Millipore (3K) centrifugal filter device and resuspended in $1.2 \%$ SDS, heated for 2 min at $95^{\circ} \mathrm{C}$ and probe sonicated. Recovered protein concentrations were normalized based on maximum protein available per condition for each sample set replicate and subsequently enriched. For enrichment of ABP-labeled proteins, an aliquot (size based on recovered protein) of streptavidin agarose resin (30$100 \mu \mathrm{L}$, Thermo Fisher), was applied to a BioRad Bio-Spin Chromatography Column equipped with a vacuum manifold. The resin was washed with PBS $(3 \times 3.0 \mathrm{~mL})$ and transferred to a vial $(4.0 \mathrm{~mL})$ using three aliquots of PBS $(0.5 \mathrm{~mL})$. Additional PBS $(1.0 \mathrm{~mL})$ was added to each tube followed by the normalized proteome sample. Each falcon tube contained a final SDS concentration of $\sim 0.2 \%$. Tubes were then rotated for $4 \mathrm{~h}$ at $37^{\circ} \mathrm{C}$. After streptavidin capture of probe-labeled proteins, resulting samples containing resin solution were transferred into a Bio-Spin column and placed on a vacuum manifold. The resin was washed with $0.5 \%$ SDS in PBS $(3 \times 1.0 \mathrm{~mL}), 6.0 \mathrm{M}$ urea in PBS $(3 \times 1.0 \mathrm{~mL})$, MilliQ water $(3$ $\times 1.0 \mathrm{~mL})$, and PBS $(5 \times 1.0 \mathrm{~mL})$. The resin was then transferred to sterile tubes $(1.5 \mathrm{~mL})$ using two aliquots of ammonium bicarbonate $(0.5 \mathrm{~mL}, 25 \mathrm{mM}, \mathrm{pH} 8)$, and the was supernatant discarded. To obtain peptides for MS analysis, an aliquot of $\mathrm{NH}_{4} \mathrm{HCO}_{3}(0.2 \mathrm{~mL}, 25 \mathrm{mM}, \mathrm{pH}$ 8) was added to the resin for each sample and treated with a trypsin solution (1-2 $\mu \mathrm{L}$, trypsin was reconstituted in $180 \mu \mathrm{L}$ of $\left.\mathrm{NH}_{4} \mathrm{HCO}_{3}\right)$. Resin solutions were heated at $37^{\circ} \mathrm{C}$ for $15 \mathrm{~h}$ with agitation. Following trypsin digestion, supernatant was collected by centrifugation at $10,500 \times g$ and placed in a sterile tube. An additional amount of $\mathrm{NH}_{4} \mathrm{HCO}_{3}(0.15 \mathrm{~mL})$ was added to sample resin and agitated on a thermal mixer at $37{ }^{\circ} \mathrm{C}$ for $10 \mathrm{~min}$. Supernatants were again collected at $10,500 \times g$ and added to corresponding tubes from prior collection. Volatiles were removed from tryptic peptide solutions by speedvac concentrator, and peptides were reconstituted in $30 \mu \mathrm{L} \mathrm{NH}_{4} \mathrm{HCO}_{3}$ by heating for $10 \mathrm{~min}$ at $37{ }^{\circ} \mathrm{C}$ with mild agitation. Samples were centrifuged in a Beckman TLA 120.1 rotor $\left(122,000 \times g, 20\right.$ min at $\left.4{ }^{\circ} \mathrm{C}\right)$ and placed in vials $(25 \mu \mathrm{L}$ aliquots) for subsequent MS analysis.

Measurement of Protein Content in Chloroflexus Cultures. Whole cell lysates were prepared for global analysis in $\mathrm{NH}_{4} \mathrm{HCO}_{3}(100 \mathrm{mM}, \mathrm{pH}$ 8.0) by bead-beating with a Bullet Blender (power setting 8), 
and protein concentrations were determined using BCA. Three replicates of whole cell lysate $(100 \mu \mathrm{g})$ were denatured and reduced by adding $8 \mathrm{M}$ urea and fresh dithiothreitol (DTT, $5 \mathrm{mM}$ ). Samples were incubated at $60{ }^{\circ} \mathrm{C}$ for $30 \mathrm{~min}$, then diluted 10-fold with $\mathrm{NH}_{4} \mathrm{HCO}_{3}(100 \mathrm{mM}, \mathrm{pH} 8.0)$ to reduce salt concentration. $\mathrm{CaCl}_{2}(1 \mathrm{mM})$ was added to the diluted samples, and proteins were digested using sequencing grade trypsin (Promega) at a ratio of 1 unit of trypsin per 50 units of protein for $3 \mathrm{~h}$ at $37^{\circ} \mathrm{C}$. Digested samples were desalted using an appropriately sized C-18 SPE column (Supelco). Sample volumes were reduced by vacuum centrifugation, and peptide concentrations determined. An equivalent amount of each sample/replicate was evaluated by LC-MS. Analysis was consistent with the methods listed above, including statistical confidence metrics.

Identification of Proteins in Cellular Extracts and Probe-Enriched Samples. Tryptic peptides were identified by LC-MS analysis using the accurate mass and time (AMT) tag and spectral count approaches with the following modifications. ${ }^{9,10}$ Probe-labeled, no probe control samples, and tryptic peptides from unprocessed cellular lysates were analyzed using an LTQ-Orbitrap (Thermo Fisher Scientific) MS interfaced with a reverse phase HPLC system for peptide separation (LC-MS). Peptides were reversephase separated on in-house manufactured columns as described previously. ${ }^{11}$ Separated peptides were ionized (positive) using an electrospray ionization interface (manufactured in-house) that consisted of chemically etched electrospray emitters $(150 \mu$ m o.d. $20 \mu \mathrm{m}$ i.d $) .{ }^{12}$ The LTQ-Orbitrap MS was operated using a heated capillary temperature and spray voltage of $200{ }^{\circ} \mathrm{C}$ and $2.2 \mathrm{kV}$, respectively. Data was acquired for $100 \mathrm{~min}$, beginning $65 \mathrm{~min}$ after sample injection (15 min into gradient). Spectra were collected from 400-2000 m/z at a resolution of $100 \mathrm{k}$, followed by data-dependent ion trap generation of MS/MS spectra of the six most abundant ions using a collision energy of $35 \%$. A dynamic exclusion time of $30 \mathrm{sec}$ was used to discriminate against previously analyzed ions.

Generated MS/MS spectra were searched using the MSGF+ algorithm against the publicly available C. aurantiacus translated genome sequence. ${ }^{13}$ Identified peptides of at least six amino acids in length having MS-GF score $\leq 1 \mathrm{E}-10$, which corresponds to an estimated FDR $<1 \%$ at the peptide level, 
were used to generate an AMT tag database. This database includes LC-MS measurements from in vitro and in vivo probe-labeled samples, and the global proteomic analyses. These same high confidence peptides were used for spectral counting, in which observations of one or more peptides for a given protein are tabulated.

Mass spectrometry spectra were deisotoped using the software tool Decon2LS, ${ }^{14}$ after which mass and elution time features were identified and matched with VIPER to peptides stored in the $C$. aurantiacus AMT tag database within mass measurement accuracy and elution time accuracy cut-offs of $<2$ ppm and $<2 \%$, respectively. ${ }^{15}$ Measured arbitrary abundance for a particular peptide was determined by integrating the area under each LC-MS peak for the detected feature matching to that peptide. Matched features from each Orbitrap dataset were then filtered on a false discovery rate (FDR) of less than or equal to $1 \% .{ }^{16}$ Peptide and protein abundances were obtained as described previously. ${ }^{11}$ Through numerous studies in various microbes we have found that biotin-based enrichment on streptavidin agarose can lead to considerably different levels of non-specific background binding of proteins to the resin. Here, we found that $C$. aurantiacus elicits a rather large background. Therefore, to mitigate false protein identifications by probe labeling we employed the following strict statistical confidence metrics to all datasets: $(i)$ only peptides unique in identifying a single protein were used; (ii) proteins represented by $<2$ unique peptides were removed; (iii) if peptides for a protein were not measured in at least half the replicates for a given limited condition they were removed from further analysis; (iv) unique peptides identified for a protein must represent $>10 \%$ of the protein sequence. We performed a case-by-case probe data analysis to identify a protein as specifically labeled by a probe by employing the following for each probe type: for $\mathbf{B}_{\mathbf{1}}-\mathbf{A B P}$ we required the AMT tag determined protein abundance in the vitamin limited datasets must be $\geq 2.0$-fold higher than the no probe (NP) control, or $\geq 4.5$-fold higher than the no probe with no click chemistry reagents (NPNoCC) control. For $\mathbf{B}_{2}$-ABP we required the AMT tag determined protein abundance must be $\geq 2$-fold higher than the NP control, or the AMT tag determined protein abundance must be $\geq 2$-fold higher than the NPNoCC control. For $\mathbf{B}_{7}$-ABP we required the AMT tag determined protein abundance must be $\geq 2.5$-fold higher than the NP control, or the AMT tag determined 
protein abundance must be $\geq 3$-fold higher than the NPNoCC control. The $\mathbf{B}_{7}$-ABP had lower fold-change requirements because of native binding of biotinylated proteins to the streptavidin resin (e.g., biotin dependent acetyl-CoA carboxylase).

\section{Supplementary References}

1. Shi, H., Cheng, X., Sze, S. K., and Yao, S. Q. (2011) Proteome profiling reveals potential cellular targets of staurosporine using a clickable cell-permeable probe, Chem. Commun. 47, 1130611308.

2. Rippka, R., Deruelles, J., Waterbury, J. B., Herdman, M., and Stanier, R. Y. (1979) Generic Assignments, Strain Histories and Properties of Pure Cultures of Cyanobacteria, J. Gen. Microbiol. 111, 1-61.

3. Hanada, S., and Pierson, B. (2006) The Family Chloroflexaceae, In The Prokaryotes (Dworkin, M., Falkow, S., Rosenberg, E., Schleifer, K.-H., and Stackebrandt, E., Eds.), pp 815-842, Springer New York.

4. Rodionova, I. A., Li, X., Plymale, A. E., Motamedchaboki, K., Konopka, A. E., Romine, M. F., Fredrickson, J. K., Osterman, A. L., and Rodionov, D. A. (2014) Genomic distribution of Bvitamin auxotrophy and uptake transporters in environmental bacteria from the Chloroflexi phylum, Environ. Microbiol. Rep. Doi:10.1111/1758-2229.12227.

5. Zerbs, S., Frank, A. M., and Collart, F. R. (2009) Bacterial systems for production of heterologous proteins, Methods Enzymol. 463, 149-168.

6. Bendtsen, J. D., Nielsen, H., von Heijne, G., and Brunak, S. (2004) Improved prediction of signal peptides: SignalP 3.0, J. Mol. Biol. 340, 783-795.

7. Yoon, J. R., Laible, P. D., Gu, M., Scott, H. N., and Collart, F. R. (2002) Express primer tool for high-throughput gene cloning and expression, Biotechniques 33, 1328-1333.

8. Giuliani, S. E., Frank, A. M., and Collart, F. R. (2008) Functional assignment of solute-binding proteins of $\mathrm{ABC}$ transporters using a fluorescence-based thermal shift assay, Biochemistry 47, 13974-13984.

9. Wiedner, S. D., Burnum, K. E., Pederson, L. M., Anderson, L. N., Fortuin, S., Chauvigne-Hines, L. M., Shukla, A. K., Ansong, C., Panisko, E. A., Smith, R. D., and Wright, A. T. (2012) Multiplexed activity-based protein profiling of the human pathogen Aspergillus fumigatus reveals large functional changes upon exposure to human serum, J. Biol. Chem. 287, 33447-33459.

10. Ansong, C., Ortega, C., Payne, S. H., Haft, D. H., Chauvigne-Hines, L. M., Lewis, M. P., Ollodart, A. R., Purvine, S. O., Shukla, A. K., Fortuin, S., Smith, R. D., Adkins, J. N., Grundner, C., and Wright, A. T. (2013) Identification of widespread adenosine nucleotide binding in Mycobacterium tuberculosis, Chem. Biol. 20, 123-133.

11. Sadler, N. C., Melnicki, M. R., Serres, M. H., Merkley, E. D., Chrisler, W. B., Hill, E. A., Romine, M. F., Kim, S., Zink, E. M., Datta, S., Smith, R. D., Beliaev, A. S., Konopka, A., and Wright, A. T. (2014) Live cell chemical profiling of temporal redox dynamics in a photoautotrophic cyanobacterium, ACS Chem. Biol. 9, 291-300. 
12. Kelly, R. T., Page, J. S., Luo, Q., Moore, R. J., Orton, D. J., Tang, K., and Smith, R. D. (2006) Chemically etched open tubular and monolithic emitters for nanoelectrospray ionization mass spectrometry, Anal. Chem. 78, 7796-7801.

13. Kim, S., Gupta, N., and Pevzner, P. A. (2008) Spectral probabilities and generating functions of tandem mass spectra: a strike against decoy databases, J. Proteome Res. 7, 3354-3363.

14. Jaitly, N., Mayampurath, A., Littlefield, K., Adkins, J. N., Anderson, G. A., and Smith, R. D. (2009) Decon2LS: An open-source software package for automated processing and visualization of high resolution mass spectrometry data, BMC Bioinformatics 10, 87.

15. Monroe, M. E., Tolic, N., Jaitly, N., Shaw, J. L., Adkins, J. N., and Smith, R. D. (2007) VIPER: an advanced software package to support high-throughput LC-MS peptide identification, Bioinformatics 23, 2021-2023.

16. Stanley, J. R., Adkins, J. N., Slysz, G. W., Monroe, M. E., Purvine, S. O., Karpievitch, Y. V., Anderson, G. A., Smith, R. D., and Dabney, A. R. (2011) A statistical method for assessing peptide identification confidence in accurate mass and time tag proteomics, Anal. Chem. 83, 6135-6140. 